\title{
Pengaruh Digital Leadership, Total Quality Management, dan Knowledge Management terhadap Sustainability Management pada Perusahaan di DKI Jakarta (The Influence of Digital Leadership, Total Quality Management, and Knowledge Management on Sustainability Management of Companies in DKI Jakarta)
}

Jennifer Wesly $^{1 *}$, Veren Kristiana ${ }^{2}$, Tommy Bong ${ }^{3}$, Nopriadi Saputra ${ }^{4}$

Jurusan Manajemen, Universitas Bina Nusantara, Jakarta Barat ${ }^{1 *, 2,3,4}$

jennifer.wesly@binus.ac.id ${ }^{l^{*}}$,veren.kristiana@binus.ac.id ${ }^{2}$, tommy.bong@binus.ac.id ${ }^{3}$, nopriadi.saputra@binus.ac.id ${ }^{4}$

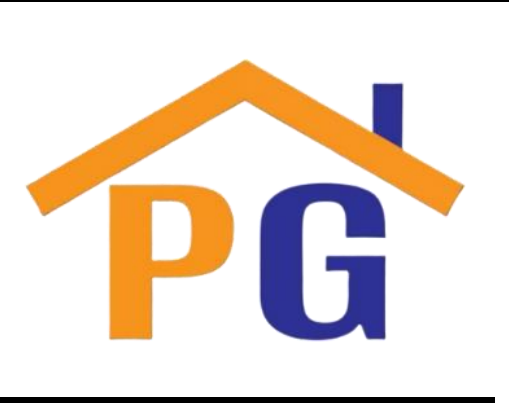

Riwayat Artikel

Diterima pada 14 Juni 2021

Direvisi pada 21 Juli 2021

Disetujui pada 4 Agustus 2021

\begin{abstract}
Purpose: This study aimed to determine the influence of digital leadership, total quality management, and knowledge management on companies' sustainability management in DKI Jakarta.

Research methodology: The sampling technique used in this research is the convenience sampling technique. It used primary data through questionnaire distribution with 389 respondents of employees who work in DKI Jakarta. As for the data analysis technique, this research used the regression technique in both simple and multiple regression.
\end{abstract}

Results: The results of this study indicate that digital leadership and knowledge management have a significant influence on the sustainability management of companies in DKI Jakarta. Meanwhile, total quality management does not have a significant influence on the sustainability management of companies in DKI Jakarta

Limitations: This study only examines the variables of digital leadership, total quality management, knowledge management, and sustainability management. This research is also limited to employees who work at companies in DKI Jakarta.

Contribution: This study shows how the level of digital leadership, total quality management, knowledge management, and sustainability management in companies in DKI Jakarta. This study also shows how digital leadership, total quality management, and knowledge management affect sustainability management. Companies can use this research to improve the company's sustainability management by implementing digital leadership, knowledge management and paying more attention to the importance of developing total quality management within the company.

Keywords: Digital Leadership, Total Quality Management, Knowledge Management, Sustainability Management

How to Cite: Wesly, J., Kristiana, V., Bong, T., \& Saputra, N. (2021). Pengaruh Digital Leadership, Total Quality Management, dan Knowledge Management terhadap Sustainability Management pada Perusahaan di DKI Jakarta. Studi Ilmu Manajemen dan Organisasi, 2(2), 97-124. 


\section{Pendahuluan}

Dunia sedang mengalami perubahan drastis terutama dalam bidang industri dan teknologi (Wrede et al., 2020). Perubahan tersebut dapat dilihat dari banyak aspek, baik dari cara manusia saling berhubungan sosial melalui media sosial cara orang menjalankan bisnis pun ikut terdampak dengan adanya bisnis-bisnis berbasis online (Setiawan, 2017). Teknologi sudah menjadi bagian dari kehidupan sehari-hari kita dimana teknologi kini dapat diakses dimana saja dan kapan saja. Dengan terjadinya perkembangan teknologi, tentunya dinamika kehidupan manusia juga turut berubah ubah. Sejak tahun 1980-an, teknologi telah berkembang dan berevolusi dimana hal ini ditandai dengan adanya pergeseran dari penggunaan teknologi mekanik menuju penerapan teknologi digital dan akan terus berkembang mengikuti perkembangan zaman (Setiawan, 2017). Revolusi Industri 4.0 ini dialami secara global oleh seluruh negara di dunia ini termasuk Indonesia yang ikut mengalami revolusi ini secara langsung.

Lompatan teknologi ini telah menyebabkan pergeseran paradigma dan memiliki dampak yang kuat pada bidang fungsional dari sistem kerja, hal seperti ini dapat juga disebut dengan adanya revolusi yang terjadi pada industri (Wilkesmann \& Wilkesmann, 2018). Dengan adanya transformasi dari teknologi digital, seseorang atau sebuah organisasi mampu untuk mendapatkan lebih banyak informasi, memudahkan komunikasi, serta memungkinkan untuk membentuk kolaborasi baru antara satu orang dengan yang lainnya (Vial, 2019). Revolusi digital saat ini mengubah hampir seluruh industri dan persaingan kompetitif perusahaan secara keseluruhan. Semakin banyak tantangan yang dihadapi dalam dunia bisnis di tengah perkembangan bisnis di era revolusi industri 4.0, salah satu tantangan utamanya adalah era VUCA yang merupakan singkatan dari Volatility, Uncertainty, Complexity, dan Ambiguity. Era VUCA memberikan gambaran situasi bisnis yang tidak memiliki kepastian dan memiliki kecenderungan untuk mudah berubah dimana hal ini dapat menimbulkan kegelisahan dari para pemimpin pada sebuah organisasi. Untuk bertahan dalam era VUCA ini perusahaan atau organisasi dituntut untuk menjadi lebih adaptif. Perusahaan tentunya perlu untuk mengatur dan merencanakan bagaimana cara mereka sustain atau bertahan dalam segi ekonomi, sosial serta lingkungan pada era baru ini.

Pada era ini, sustainability sedang menjadi topik hangat dimana dengan adanya peran teknologi dan komunikasi yang diimplementasikan pada sebuah organisasi atau perusahaan diperkirakan mampu untuk mengurangi jejak karbon dan emisi global namun juga tetap memperhatikan atau memerhatikan pertumbuhan ekonomi dalam sebuah perusahaan (Al-Khouri, 2013). Sustainability Management merupakan sebuah penerapan atau praktik berkelanjutan yang mencangkup kategori dari binis atau ekonomi, sosial dan linkungan dengan mengelolanya dengan cara yang akan memberikan manfaatmanfaat bagi generasi saat ini dan generasi mendatang untuk mencapai tujuan yang sinergis bagi perusahaan (Choudhury, 2019).

Berdasarkan penelitian terdahulu dan juga studi pustaka yang dilakukan, terdapat beberap faktor yang mempengarui sustainability management pada sebuah perusahaan. faktor-faktor tersebut adalah Digital Leadership, Total Quality Management dan juga Knowledge Management. Para peneliti terdahulu menyatakan bahwa seorang Digital leader memainkan peran yang penting dalam memastikan terjadinya transformasi digital yang sesuai dengan visi dan misi yang mereka miliki, sehingga penilaian kinerja berdasarkan bagaimana kematangan digital dan pengembangan perusahaan berdasarkan keunggulan dari operasi digital atau budaya digital yang dimilikinya (Mihardjo et al., 2019).

Sedangkan faktor lainnya seperti Total Quality Management dianggap penting bagi perusahaan untuk mempertahankan keberlangsungan perusahaan dengan membantu perusahaan untuk meingkatkan kualitas dari produk atau jasa yang dimilikinya. Knowledge Management juga diharapkan untuk dapat menjaga competitive advantage yang dimiliki oleh perusahaan dengan ilmu yang tersebar dan merata di seluruh jajaran pekerja dan karyawan perusahaan, sehingga secara tidak langsung seluruh bagian dari perusahaan adalah aset intelektual yang berguna bagi perusahaan tersebut (Razmerita et al., 2016).

Untuk itu, penelitian ini dilakukan untuk melakukan identifikasi apakah terdapat pengaruh dari Digital Leadership, Total Quality Management dan Knowledge Management terhadap Sustainability Management pada perusahaan di DKI Jakarta. 


\section{Tinjauan Pustaka Dan Pengembangan Hipotesis}

Pada bagian ini peneliti akan menjelaskan lebih dalam mengenai Digital Leadership, Total Quality Management dan Knowledge Management dan Sustainability Management berdasarkan penelitian terdahulu yang relevan.

\section{Sustainability Management (Manajemen Keberlanjutan)}

Untuk bertahan dalam industri perusahaan tentu memiliki caranya masing-masing dalam menjalankan atau mempertahankan usaha atau bisnis nya. Hal-hal semacam ini tentunya merupakan hal-hal yang krusial dimana perusahaan harus bisa sebaik mungkin untuk mengatur bagaimana usahanya dapat bertahan dalam pasar. Sustainability disini membahas mengenai bagaimana kemampuan organisasi untuk mampu memenuhi kebutuhan bisnis yang ada dan memiliki kemampuan untuk mempersiapkan dan menanggapi kebutuhan bisnis dan pasar secara strategis di masa yang akan datang (Tasleem et al., 2019). Sustainability Management merupakan sebuah penerapan atau praktik berkelanjutan yang mencangkup kategori dari binis atau ekonomi, sosial dan linkungan dengan mengelolanya dengan cara yang akan memberikan manfaat-manfaat bagi generasi saat ini dan generasi mendatang untuk mencapai tujuan yang sinergis bagi perusahaan (Choudhury, 2019).

Salah satu alasan untuk fokus pada sustainable management adalah untuk mengurangi dampak negatif pada lingkungan dan sosial dari kegiatan usaha perusahaan namun tetap fokus untuk meningkatkan atau setidaknya tidak mengurangi kinerja ekonomi dari sebuah perusahaan (Baumgartner \& Rauter, 2017). Selain itu, penelitian yang dilakukan juga sering membahas mengenai dampak positif dari sustainability management diantaranya adalah: pengurangan biaya, pengurangan resiko, peningkatan penjualan, inovasi dari model bisnis, meningkatkan daya tarik perusahaan, meningkatkan reputasi perusahaan serta menciptakan inovasi hasil dari kolaborasi dengan para stakeholder (pemangku kepentingan) (Kiesnere \& Baumgartner, 2019). Sustainability management juga memberikan dampak positif yang tidak dapat diukur dengan pengukuran akutansi yaitu peningkatan produktivitas karyawan (Kim \& Kim, 2018).

\section{Digital Leadership (Kepemimpinan Digital)}

Dalam sebuah perusahaan tentunya terdapat pemimpin yang bertugas untuk memimpin para pekerjanya dalam kegiatan keseharian perusahaan atau organisasi. Kepemimpinan merupakan sebuah proses mempengaruhi para pengikutnya demi mencapai tujuan sebuah organisasi atau perusahaan Erkollar, 2018). Dengan adanya perkembangan tenologi, tidak dapat dipungkiri bahwa hal tersebut juga menggeser bagaimana cara seorang pemimpin memimpin perusahaannya. Lompatan teknologi ini telah menyebabkan pergeseran paradigma dan memiliki dampak yang kuat pada bidang fungsional dari sistem kerja, hal seperti ini dapat juga disebut dengan adanya revolusi yang terjadi pada industri (Wilkesmann \& Wilkesmann, 2018). Oleh karena itu, dibutuhkannya seorang pemimpin yang peka terhadap perkembangan teknologi yang ada serta tidak menentang penggunaan teknologi yang dapat diadopsi dengan tujuan untuk membantu kegiatan usaha di perusahaan atau organisasinya.

Digital leadership merupakan kemampuan seorang pemimpin dalam menggunakan teknologi digital untuk memberikan pengaruhnya serta arahannya kepada anggota tim yang dimiliki sehingga tujuan yang telah ditetapkannya dapat tercapai (Saputra \& Saputra, 2020). Seorang pemimpin harus bisa menentukan apa yang terbaik untuk organisasi atau perusahaan yang dipimpinnya. Seorang pemimpin harus mampu untuk mengetahui apa kelebihan serta kekurangan yang dimiliki sehingga langkah yang akan diambil akan tepat sasaran dan menciptakan sebuah nilai baru bagi perusahaan. Untuk itu, seperti penelitian yang dilakukan terdahulu oleh Pantouvakis dan Vlanchos dimana mereka menemukan bahwa kepemimpinan dari seorang leader memiliki peran yang sangat penting dalam keberlangsungan perusahaan (Pantouvakis \& Vlachos, 2020).

\section{H1: Digital Leadership secara signifikan mempengaruhi Sustainability Management}

Dalam penelitian yang telah dilakukan, didapatkan bahwa dimensi yang dimiliki dalam Digital Leadership itu sendiri adalah Digital Attitude dan juga Leadership Skill (Saputra \& Saputra, 2020). Digital Attitude adalah sebuah pandangan seseorang atau para pekerja mengenai teknologi digital yang digunakan perusahaan untuk membantu mereka dalam kegiatan organisasi atau perusahaan (Rudito \& Sinaga, 2017). Sedangkan, Leadership skill adalah kemampuan pemimpin untuk melakukan 
pengarahan karyawan-karyawannya dalam perusahaan untuk mengejar visi serta misi yang sama dalam berkembang di era digital (Rudito \& Sinaga, 2017).

Studi empiris terdahulu yang dilakukan dengan menggunakan metode kuesioner sebagai metode pengumpulan data yang disebarkan pada pegawai pada 250 pegawai pada industri migas di Balikpapan Indonesia menemukan bahwa terdapat pengaruh yang positif antara kepemimpinan dengan total quality management (Wagimin et al., 2019).

\section{H2: Digital Leadership secara signifikan mempengaruhi Total Quality Management}

Digital leadership juga dapat didefinisikan sebagai sebuah pendekatan yang cepat, kooperatif dan juga yang berorientasi pada kerjasama tim dengan memiliki fokus yang kuat pada inovasi dimana seorang pemimpin yang berorientasi digital ini memiliki kemampuan untuk menerapkan metode dan instrumen yang baru sehingga dapat menciptakan sebuah solusi dari masalah yang kompleks dan juga untuk menjaga keberlangsungan bisnisnya_(Oberer \& Erkollar, 2018). Dengan menggunakan teknologi digital berbasis internet dan cloud, seorang pemimpin dituntut untuk memiliki kemampuan serta pengetahuan yang mendalam mengenai perkembangan teknologi dan penerapannya (Mihardjo et al., 2019).

Berdasarkan penelitian terdahulu yang telah dilakukan dimana peneliti melakukan analisis dari 353 data yang dikumpulkan dari 56 perusahaan manufaktur dan jasa menemukan bahwa kepemimpinan mempengaruhi secara positif dari budaya knowledge sharing (Le \& Lei, 2017). Variabel knowledge sharing merupakan salah satu indikator dari siklus Knowledge Management.

\section{H3: Digital Leadership secara signifikan mempengaruhi Knowledge Management}

\section{Total Quality Management (Manajemen Kualitas Total)}

Kualitas adalah kesesuaian dengan kebutuhan, artinya produk dan jasa yang berkualitas bila memiliki standar kulitas yang dapat diukur dengan jelas dan standar kualitas meliputi bahan baku utama, proses produksi hingga produk jadi (Crosby et al., 1992). Total Quality Management juga difokuskan untuk semua pemangku kepentingan organisasi untuk meningkatkan kinerja manajemen yang mengedepankan pendidikan pelatihan dan pelayanan khususnya untuk industri jasa dan pelayanan (Hota et al., 2021). Total Quality Management juga merupakan sebuah upaya dari seluruh entitas di dalam organisasi dalam membuat iklim dimana organisasi tersebut akan terus meningkatkan kemampuan mereka dalam memberikan produk-produk atau layanan yang berkualitas tinggi kepada pelanggan sehingga terciptanya customer satisfaction (Kepuasan pelanggan) (Charantimath, 2017).

Deming juga mengungkapkan bahwa dasar dari pengertian Total Quality Management berasal dari definisi apa itu kualitas. Produk atau jasa yang baik merupakan produk atau jasa yang memiliki kualitas dimana dengan kualitas tersebut dapat membantu konsumen dan membantu perusahaan dalam mencapai sustainability (keberlangsungan) (Deming, 2000). Untuk mendorong implementasi Total Quality Management yang maksimal maka harus memperhatikan beberapa dimensi-dimensi Total Quality Management. Dimensi-dimensi dari Total Quality Management itu sendiri antara lain: (1) Komitmen Management Puncak, (2) Keterlibatan Karyawan, (3) Kepuasan Pelanggan, (4) Kerja Sama Tim, (5) Proses, (6) Perbaikan Secara Berkelanjutan (Daqar \& Constantinovits, 2020).

\section{H4: Total Quality Management secara signifikan mempengaruhi Sustainability Management}

\section{Knowledge Management (Manajemen Pengetahuan)}

Pengetahuan adalah aset tak berwujud dan tidak dapat ditiru yang diperoleh oleh seseorang berdasarkan pengalaman, pembelajaran, dan pengertian terhadap sesuatu baik secara teoritis maupun praktis yang digunakan sebagai sebuah instrumen kompetitif dan digunakan secara efisien oleh organisasi (Shahzad et al., 2020). Pengetahuan dapat juga dilihat sebagai sebuah konsep, keterampilan, pengalaman, dan pandangan yang memberikan suatu gambaran dasar dalam membuat, menilai, melakukan evaluasi, serta menggunakan atau memanfaatkan informasi yang dimiliki (Soltani \& Navimipour, 2016).

Sumber daya pengetahuan diakui sebagai aset strategis yang penting dalam membangun performa organisasi yang superior dan keunggulan kompetitif yang berkelanjutan di lingkungan bisnis yang dinamis dan menantang (Iqbal et al., 2019). Knowledge Management merupakan suatu upaya untuk 
mengidentifikasi, menangkap, menyimpan, menyebarkan dan mengaplikasikan pengetahuan ke seluruh bagian organisasi agar proses bisnis dapat diselesaikan dengan lebih cepat dan efisien (Mohapatra et al., 2016). Knowledge management merupakan sebuah cara yang dapat digunakan oleh organisasi untuk membagikan informasinya kepada seluruh bagian di organisasi sehingga dapat mengurangi hal-hal yang tumpang tindih serta meningkatkan efektivitas dan efisiensi dari kegiatan perusahaan tiap harinya (Ichijo et al., 2007).

Tujuan penting knowledge management adalah memperbaiki efektivitas perusahaan melalui pengetahuan dan meningkatkan kemampuan organisasi untuk berinovasi menggunakan pengetahuan tersebut dan agar pengetahuan tersebut dapat digunakan kembali.

Penelitian empiris terdahulu yang ditemukan oleh peneliti menunjukan bahwa terdapat pengaruh antara variabel-variabel indikator dari Knowledge Management Process terhadap Sustainability Management (Demir et al., 2021).

\section{H5: Knowledge Management secara signifikan mempengaruhi Sustainability Management}

Knowledge management dipandang sebagai sebuah proses sehingga dapat diartikan ada banyak kegiatan yang dibentuk untuk mengelola elemen-elemen dari knowledge management (Aziz, 2020). Terdapat banyak sekali proses knowledge management telah dipublikasikan oleh para peneliti terdahulu melalui berbagai perspektif. Pertama dimulai dari memperoleh dan menciptakan pengetahuan (Creation), transfer pengetahuan (Transfer), penyimpanan pengetahuan (Storage), dan aplikasi pengetahuan (Application). Knowledge creation atau capture (Penciptaan Pengetahuan) ditujukan ke bagaimana kemampuan dalam membuat ide atau solusi yang baru dan bermanfaat mulai dari berbagai aspek di perusahaan seperti, aktivitas perusahaan, produk atau jasa, dan proses penggunaan teknologi untuk praktik manajemen di perusahaan (Kianto et al., 2016). Knowledge storage mengacu kepada bagaimana proses dalam mencatat dan menyimpan sumber pengetahuan kemudian disimpan dalam beberapa bentuk repositori seperti database perusahaan atau organisasi dan arsip (Fernández, 2015). Knowledge transfer merupakan proses yang penting dalam knowledge management. Knowledge application mengacu kepada aktualisasi atau realisasi dari pengetahuan. Pada tahap terakhir, proses ini digunakan untuk memanfaatkan pengetahuan yang telah ada atau dibuat untuk digunakan secara maksimal dalam penerapannya (Yusr et al., 2017).

Dengan adanya informasi yang terus-menerus diturunkan pada perusahaan diharapkan perusahaan mendapatkan informasi untuk menangani permasalahan yang akan terjadi, perencaan strategi serta meningkatkan kualitas dari produk atau jasa yang diberikan.

Penelitian terdahulu dilakukan dengan menggunakan penelitian kuantitatif, melalui kuisioner yang telah di bagikan kepada seluruh karyawan bank di Yordania dengan tingat pengambilan data sebanyak 250 responden serta mengunakan analisis regresi menemukan bahwa Knowledge Management secara signifikan mempengaruhi implementasi Total Quality Management (Obeidat et al., 2018).

\section{H6: Knowledge Management secara signifikan mempengaruhi Total Quality Management}

\section{Kerangka Berpikir}

Penelitian yang akan dilakukan oleh peneliti memiliki tiga variabel independen dan satu variabel dependen. Seperti gambar yang dapat kita lihat di atas bahwa variabel independen meliputi Digital Leadership $\left(\mathrm{X}_{1}\right)$, Total Quality Management $\left(\mathrm{X}_{2}\right)$ dan Knowledge Management $\left(\mathrm{X}_{3}\right)$. Sedangkan, variabel dependen dari penelitian ini adalah Sustainability Management (Y). Model dari kerangka berpikir atau hipotesis yang dirancang oleh peneliti dalam penelitian ini antara lain: 


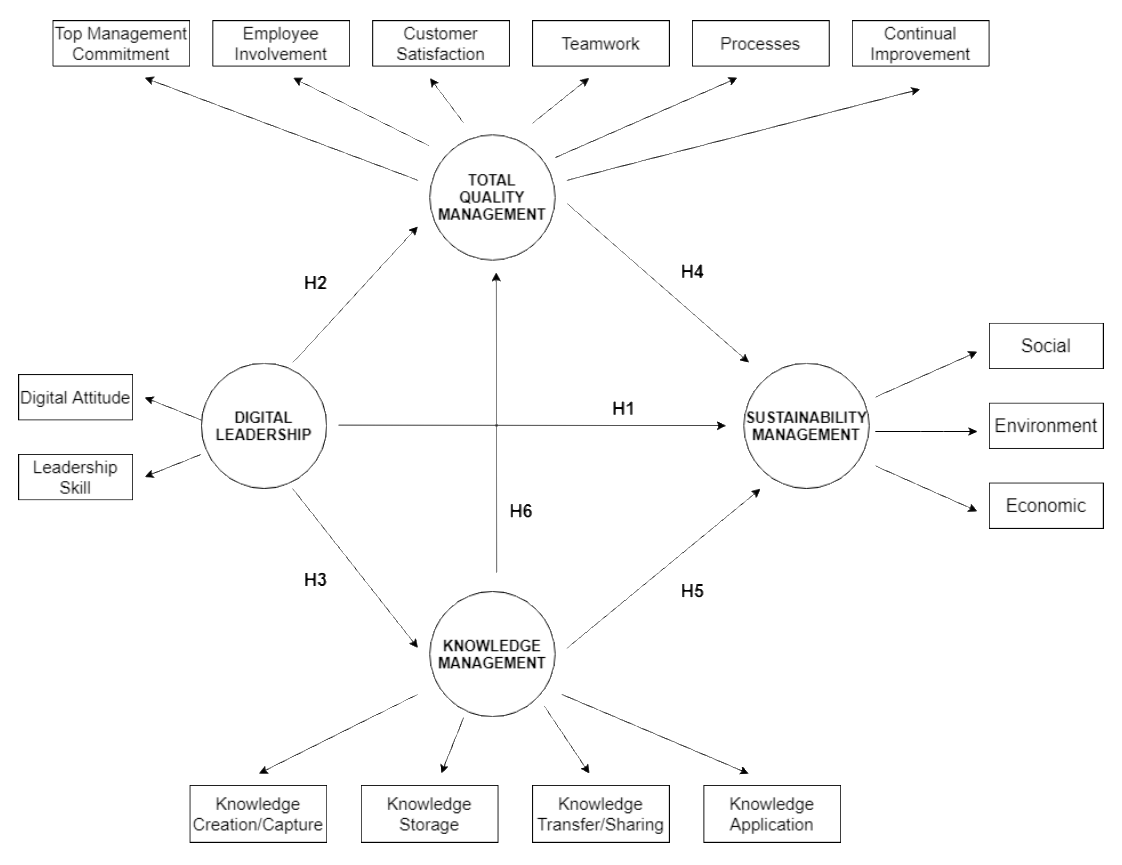

Gambar 1 Kerangka Berpikir

Sumber: Peneliti (2021)

Hipotesis:

- H1: Digital Leadership secara signifikan mempengaruhi Sustainability Management

- H2: Digital Leadership secara signifikan mempengaruhi Total Quality Management

- H3: Digital Leadership secara signifikan mempengaruhi Knowledge Management

- H4: Total Quality Management secara signifikan mempengaruhi Sustainability Management

- H5: Knowledge Management secara signifikan mempengaruhi Sustainability Management

- H6: Knowledge Management secara signifikan mempengaruhi Total Quality Management.

\section{Metode Penelitian}

Penelitian ini menggunakan metode penelitian kuantitatif. Penelitian kuantitatif adalah salah satu jenis metode penelitian yang didasarkan pada cara pandang ilmu pengetahuan dunia dengan sains ilmiah atau berdasarkan fakta yang terjadi, dalam prakteknya digunakan untuk melakukan penelitian pada populasi atau sampel tertentu dengan cara mengumpulkan data menggunakan instrumen penelitian, analisis data bersifat kuantitatif atau statistik berupa angka yang pasti di lapangan, hal ini bertujuan untuk menguji hipotesis yang telah ditetapkan sebelumnya (Fatimah Mardani \& Wahono, 2017).

Sumber data yang digunakan dalam penelitian ini adalah sumber data primer dan sekunder. Sumber data primer merupakan sekumpulan data atau informasi yang dikumpulkan untuk tujuan tertentu dari sebuah penelitian yang dilakukan dimana data primer dapat dikumpulkan oleh peneliti itu sendiri atau orang lain (Kumar, 2019). Data primer dalam penelitian ini berasal dari hasil kuesioner yang disebarkan kepada para pegawai di DKI Jakarta. Sedangkan, data sekunder adalah Sekumpulan data atau informasi yang telah ada sebelumnya berupa jurnal, laporan atau sensus yang dapat digunakan oleh peneliti sebagai bahan penelitian (Kumar, 2019). Data sekunder yang akan digunakan oleh peneliti adalah berupa data yang didapatkan dari jurnal-jurnal penelitan terdahulu dan juga website pemerintah.

\section{Teknik pengambilan sampel}

Penelitiain ini berfokus pada pegawai di DKI Jakarta. Berdasarkan data yang diperoleh dari Portal Statistik Sektoral Provinsi DKI Jakarta, diperoleh data bahwa jumlah populasi pegawai di DKI Jakarta pada tahun 2019 sebanyak 4.836.977 orang (Putra, 2020). Berdasarkan jumlah populasi tersebut, untuk menghitung jumlah sampel yang harus diambil, peneliti menggunakan rumus Krejcie dan Morgan yaitu:

$$
s=X^{2} N P(1-P) \div d^{2}(N-1)+X^{2} P(1-P)
$$




\section{Keterangan:}

$\mathrm{S} \quad=$ Jumlah sampel yang dibutuhkan

$\mathrm{X}^{2} \quad=$ Nilai dari chi-square untuk 1 derajat kebebasan pada tingkat kepercayaan yang diinginkan (3.841)

$\mathrm{N} \quad=$ Jumlah populasi

$\mathrm{P} \quad=$ Proporsi populasi (diasumsikan sebagai 0.50 karena ini akan memberikan ukuran sampel maksimum)

$\mathrm{D} \quad=$ Tingkat akurasi yang dinyatakan sebagai proporsi (0.05)

Berdasarkan metode perhitungan Krejcie dan Morgan tersebut diperoleh bahwa jumlah sampel dalam penelitian ini adalah sebanyak 389 responden. Teknik sampling yang akan digunakan adalah Convenience Sampling Technique. Convenience Sampling Technique adalah sebuah teknik sampling dimana peneliti mengumpulkan data atau informasi dari populasi yang telah tersedia untuk menyediakannya (Sekaran \& Bougie, 2016). Dimana sebesar 100 data dari 389 responden merupakan pegawai dari PT. Perusahaan Pengelola Aset (PERSERO). Kemudian 289 dari 389 data merupakan data yang peneliti dapatkan dari pegawai perusahaan di DKI Jakarta selain dari pegawai PT. Perusahaan Pengelola Aset (PERSERO).

\section{Metode Pengumpulan Data}

Metode pengumpulan data yang digunakan di dalam penelitian ini adalah menyebarkkan kuesioner dengan menggunakan Google Form sebagai perantara untuk menyebarkan kuesioner. Skala pengukuran kuesioner dengan skala 1-5. Skala nilai 1 merupakan nilai terendah "Tidak Pernah" sedangkan nilai 5 merupakan nilai tertinggi "Selalu". Berdasarkan kuesioner yang disebarkan oleh responden, peneliti memperoleh responden sebanyak 389 orang.

\section{Metode Analisis Data}

Metode analisis data yang digunakan dalam penelitian ini ada uji statistic deskriptif, uji validitas dan reliabilitas, uji tabulasi silang (Independent Sample t-test dan Kruskal-Wallis), dan uji hipotesis dengan melakukan uji regresi. Pengolahan data dilakukan dengan menggunakan aplikasi SPSS 26.

\section{- Uji Validitas dan Reliabilitas}

Uji Validitas merupakan sebuah uji yang menunjukkan sejauh mana penelitian atau pengamatan yang dilakukan dalam mencatat perilaku dari sampel dengan akurat sehingga data yang dihasilkan adalah benar dan sesuai (Sekaran \& Bougie, 2016). Pengambilan keputusan dalam uji validitas dilakukan dengan membandingkan nilai $\mathrm{R}$ hitung dengan $\mathrm{R}$ tabel:

$\mathrm{R}$ hitung $\geq \mathrm{R}$ tabel $\rightarrow$ data valid

$$
\mathrm{R} \text { hitung }<\mathrm{R} \text { tabel } \rightarrow \text { data tidak valid }
$$

Uji Reliabilitas adalah uji yang dilakukan untuk mengetahui konsistensi dari instrumeninstrumen yang ada dalam penelitian sehingga data yang dikumpulkan oleh peneliti memiliki hasil yang sama secara konsisten (Sekaran \& Bougie, 2016). Pengambilan keputusan dalam uji reliabilitas dilakukan dengan menganalisis nilai Cronbach Alpha dari Nunnally (1978), yaitu $\alpha=0.7$ (Knapp \& Brown, 1995):

$$
\begin{gathered}
\mathrm{R} \alpha \geq 0.7 \rightarrow \text { data reliabel } \\
\mathrm{R} \alpha<0.7 \rightarrow \text { data tidak reliabel }
\end{gathered}
$$

\section{- Uji Statistik Deskriptif}

Penelitian deskriptif atau juga dikenal sebagai statistik deskriptif merupakan sebuah metode yang dapat digunakan dengan tujuan untuk melakukan pengorganisasian dari sekumpulan data, peringkasan serta penyajian data secara informatif (Lind et al., 2017). Statistik deskriptif juga digunakan untuk mengatur data dengan menunjukan pola umum dari data yang dikumpulkan, melakukan identifikasi dari kecenderungan nilai-nilai data serta mengekspos dari nilai dari data yang ekstrim atau tidak biasa (Lind et al., 2017). 


\section{- Uji Tabulasi Silang (Independent Sample t-test dan Kruskal-Wallis)}

Uji Independent Sample $t$ Test merupakan sebuah uji statistik yang dipergunakan untuk mengetahui apakah terdapat perbedan nilai rata-rata yang signifikan dari sampel yang diambil secara acak dari populasi yang sama (Lind et al., 2017). Pengambilan keputusan dalam Independent Sample t-test dilakukan dengan membandingkan antara nilai t hitung dengan nilai $t$ tabel dan antara nilai sig. dengan nilai $\alpha$ pada level of significance $(0,05)$

$\mathrm{t}$ hitung $\leq \mathrm{t}$ tabel dan $\mathrm{Sig} \geq \alpha \rightarrow \mathrm{H}_{0}$ diterima atau $\mathrm{H}_{\mathrm{a}}$ ditolak t hitung $>\mathrm{t}$ tabel dan $\mathrm{Sig}<\alpha \rightarrow \mathrm{H}_{0}$ ditolak atau $\mathrm{H}_{\mathrm{a}}$ diterima

Kruskal-Wallis merupakan sebuah uji yang digunakan untuk melakukan analisis varians parametrik atau ANOVA tidak dapat dipenuhi dimana tujuan dari uji Kruskal-Wallis itu sendiri adalah untuk mengetahui apakah terdapat kesamaan dalam beberapa populasi (Lind et al., 2017). Pengambilan keputusan dalam uji Kruskal-Wallis dilakukan dengan membandingkan antara nilai $\mathrm{X}^{2}$ hitung dengan nilai $\mathrm{X}^{2}$ tabel dan antara nilai sig. dengan nilai $\alpha$ pada level of significance $(0,05)$ :

$$
\begin{aligned}
& X^{2} \text { hitung } \leq X^{2} \text { tabel dan Sig } \geq \alpha \rightarrow H_{0} \text { diterima atau } H_{a} \text { ditolak } \\
& X^{2} \text { hitung }>X^{2} \text { tabel dan Sig }<\alpha \rightarrow H_{0} \text { ditolak atau } H_{a} \text { diterima }
\end{aligned}
$$

\section{- Uji Hipotesis (Regresi)}

Perhitungan regresi berganda digunakan untuk membentuk perhitungan persamaan regresi dari lebih satu variabel independen terhadap satu variabel dependen. Sedangkan, untuk membentuk persamaan regresi antara satu variabel independen terhadap satu variabel dependen. Berikut ini adalah model persamaan regresi:

$$
Y=a+b_{1} X_{1}+b_{2} X_{2}+b_{3} X_{3}+\ldots++b_{K} X_{K}+\varepsilon
$$

Keterangan:

$a \quad=$ Intercept ketika seluruh $\mathrm{x}$ adalah nol

$\mathrm{b} \quad=$ Nilai koefisien regresi

$\varepsilon \quad=$ Error (Variabel lain yang tidak diteliti)

$\mathrm{X}_{\mathrm{K}} \quad=$ Nilai dari variabel independen

Pada perhitungan regresi juga diperoleh nilai koefisien determinasi $\left(\mathrm{R}^{2}\right)$ yang dapat digunakan untuk mengukur seberapa akurat model regresi dapat menjelaskan kemampuan variabel independen dalam menjelaskan variasi variabel dependen. Nilai koefisien determinasi berada direntang antara nol sampai dengan satu, semakin nilai koefisien determinasi mendekati nilai satu, maka variabel independen dapat menjelaskan variasi variabel dependen dengan baik.

Peneliti menggunakan nilai uji-t dengan tujuan untuk menguji hipotesis berdasarkan bukti dari sampel dan juga teori probabilitas sehingga dapat menjadi bukti yang mendukung kebenaran dari hipotesis tersebut (Sekaran \& Bougie, 2016). Melalui perhitungan uji-t, peneliti dapat mengetahui apakah terdapat pengaruh antara satu variabel independen terhadap satu variabel dependen. Pengambilan keputusan dalam uji-t dilakukan dengan membandingkan antara nilai thitung dengan nilai $t$ tabel dan antara nilai sig. dengan nilai $\alpha$ pada level of significance $(0,05)$ :

$$
\begin{aligned}
& \mathrm{t} \text { hitung } \leq \mathrm{t} \text { tabel dan } \mathrm{Sig} \geq \alpha \rightarrow \mathrm{H}_{0} \text { diterima atau } \mathrm{H}_{\mathrm{a}} \text { ditolak } \\
& \mathrm{t} \text { hitung }>\mathrm{t} \text { tabel dan } \mathrm{Sig}<\alpha \rightarrow \mathrm{H}_{0} \text { ditolak atau } \mathrm{H}_{\mathrm{a}} \text { diterima }
\end{aligned}
$$

\section{- Path Analysis (Analisa Jalur)}

Path analysis atau yang dikenal sebagai analisis jalur adalah sebuah variasi dari rergresi berganda dimana analisis ini berguna untuk menganalisis masalah-masalah dalam analisis kausal atau menjelaskan hubungan kasual antara satu set variabel independen dan variabel dependen serta menguji asumsi hubungan antara variabel independen (Nayebi, 2020; Stage et al., 2004). Dengan menggunakan analisis jalur peneliti dapat menunjukan efek unik dari setiap variabel-variabel independen terhadap variabel dependen (Nayebi, 2020). 


\section{Hasil Dan Pembahasan}

\section{Profil responden penelitian}

Tabel 1. Profil Responden Penelitian

\begin{tabular}{|c|c|c|c|c|}
\hline \multicolumn{5}{|c|}{ Profil Responden } \\
\hline Sumber & PT. Perusahaan Pengelola Aset & 100 & $25.7 \%$ & $25.7 \%$ \\
\hline Data & Lainnya & 289 & $74.3 \%$ & $100.0 \%$ \\
\hline \multirow{2}{*}{ Jenis Kelamin } & Pria & 194 & $49.9 \%$ & $49.9 \%$ \\
\hline & Wanita & 195 & $50.1 \%$ & $100.0 \%$ \\
\hline \multirow{5}{*}{ Usia } & $\leq 21$ tahun & 73 & $18.8 \%$ & $18.8 \%$ \\
\hline & $22-25$ tahun & 163 & $41.9 \%$ & $60.7 \%$ \\
\hline & 26-30 tahun & 57 & $14.7 \%$ & $75.3 \%$ \\
\hline & 31-35 tahun & 23 & $5.9 \%$ & $81.2 \%$ \\
\hline & $>35$ tahun & 73 & $18.8 \%$ & $100.0 \%$ \\
\hline \multirow{5}{*}{ Pendidikan } & SMA/SMK & 87 & $22.4 \%$ & $22.4 \%$ \\
\hline & Diploma & 15 & $3.9 \%$ & $26.2 \%$ \\
\hline & Sarjana (S1) & 257 & $66.1 \%$ & $92.3 \%$ \\
\hline & Magister (S2) & 28 & $7.2 \%$ & $99.5 \%$ \\
\hline & Doktoral (S3) & 2 & $0.5 \%$ & $100.0 \%$ \\
\hline \multirow{2}{*}{ Jenis Perusahaan } & Perusahaan BUMN & 115 & $29.6 \%$ & $29.6 \%$ \\
\hline & Perusahaan Swasta & 274 & $70.4 \%$ & $100.0 \%$ \\
\hline \multirow{4}{*}{$\begin{array}{l}\text { Lama } \\
\text { Bekerja }\end{array}$} & $\leq 1$ tahun & 185 & $47.6 \%$ & $47.6 \%$ \\
\hline & $\overline{2}-5$ tahun & 129 & $33.2 \%$ & $80.7 \%$ \\
\hline & $6-15$ tahun & 55 & $14.1 \%$ & $94.9 \%$ \\
\hline & $>15$ tahun & 20 & $5.1 \%$ & $100.0 \%$ \\
\hline \multirow{8}{*}{$\begin{array}{l}\text { Posisi/ } \\
\text { Jabatan }\end{array}$} & Staff/Karyawan & 239 & $61.4 \%$ & $61.4 \%$ \\
\hline & Kepala Unit & 36 & $9.3 \%$ & $70.7 \%$ \\
\hline & Kepala Grup & 20 & $5.1 \%$ & $75.8 \%$ \\
\hline & Kepala Divisi & 15 & $3.9 \%$ & $79.7 \%$ \\
\hline & Supervisor/Kepala Staff & 35 & $9.0 \%$ & $88.7 \%$ \\
\hline & Manager & 20 & $5.1 \%$ & $93.8 \%$ \\
\hline & Direktur & 3 & $0.8 \%$ & $94.6 \%$ \\
\hline & Internship/Magang & 21 & $5.4 \%$ & $100.0 \%$ \\
\hline \multirow{12}{*}{ Jenis Industri } & Bahan Baku & 7 & $1.8 \%$ & $1.8 \%$ \\
\hline & Jasa & 91 & $23.4 \%$ & $25.2 \%$ \\
\hline & Barang Konsumen Primer & 23 & $5.9 \%$ & $31.1 \%$ \\
\hline & Barang Konsumen Non-Primer & 23 & $5.9 \%$ & $37.0 \%$ \\
\hline & Energi atau Pertambangan & 5 & $1.3 \%$ & $38.3 \%$ \\
\hline & Keuangan & 136 & $35.0 \%$ & $73.3 \%$ \\
\hline & Kesehatan & 5 & $1.3 \%$ & $74.6 \%$ \\
\hline & Industri atau Pabrik & 28 & $7.2 \%$ & $81.7 \%$ \\
\hline & Infrastruktur & 8 & $2.1 \%$ & $83.8 \%$ \\
\hline & Properti dan Real Estate & 7 & $1.8 \%$ & $85.6 \%$ \\
\hline & Teknologi & 52 & $13.4 \%$ & $99.0 \%$ \\
\hline & Transportasi dan Logistik & 4 & $1.0 \%$ & $100.0 \%$ \\
\hline
\end{tabular}

Dari tabel diatas diketahui bahwa sebesar $74 \%$ responden dalam penelitian ini berasal dari luar PT. PPA dan jika dipisahkan berdasarkan jenis kelamin, sebesar 50,1\% responden berjenis kelamin perempuan, perbedaan jumlah responden perempuan laki-laki hanya berbeda satu orang. Berdasarkan usia, terdapat sebesar 41,9\% responden berusia 22-25 tahun, sebesar 66\% responden memiliki latar belakang pendidikan sampai dengan Sarjana (S1). Berdasarkan perusahaan tempat bekerja, sebesar 70\% responden bekerja di perusahaan swasta dan sebesar $47 \%$ responden memiliki masa kerja dibawah sampai dengan satu tahun. Responden penelitian ini dominan memiliki posisi sebagai staff dengan nilai sebesar $61 \%$ dan sebesar 35\% responden bekerja pada industri financial. 
Analisa Deskriptif Variabel

Tabel 2. Analisis Deskriptif Variabel

\begin{tabular}{|c|c|c|c|c|c|c|}
\hline Variabel & Dimensi & Indikator & $\mathbf{N}$ & Validitas & Reliabilitas & Rerata \\
\hline \multirow{14}{*}{$\begin{array}{l}\text { Sustainability } \\
\text { Management } \\
\text { (Y) }\end{array}$} & & & & & 0,898 & 4,06 \\
\hline & \multirow[t]{6}{*}{ Ekonomi } & & & & & 4,11 \\
\hline & & $\begin{array}{l}\text { Perusahaan melakukan } \\
\text { kegiatan research } \\
\text { (penelitian) dan } \\
\text { development } \\
\text { (pengembangan) untuk } \\
\text { produk/servis baru dengan } \\
\text { menggunakan teknologi. }\end{array}$ & 389 & 0,455 & & 3,84 \\
\hline & & $\begin{array}{l}\text { Perusahaan melakukan } \\
\text { kerjasama dan kolaborasi } \\
\text { dengan berbagai pihak } \\
\text { dalam pengembangan } \\
\text { produk atau jasa. }\end{array}$ & 389 & 0,456 & & 4,16 \\
\hline & & $\begin{array}{l}\text { Terdapat kegiatan } \\
\text { pembagian pengetahuan } \\
\text { untuk mempertahankan } \\
\text { pegetahuan dalam } \\
\text { perusahaan. }\end{array}$ & 389 & 0,641 & & 4,1 \\
\hline & & $\begin{array}{l}\text { Perusahaan memiliki } \\
\text { kejelasan dalam proses } \\
\text { serta tanggungjawab dari } \\
\text { setiap anggota perusahaan } \\
\text { dalam bekerja. }\end{array}$ & 389 & 0,682 & & 4,25 \\
\hline & & $\begin{array}{l}\text { Perusahaan melakukan } \\
\text { pencatatan dalam segala } \\
\text { kegiatan yang dilakukan } \\
\text { atau Sustainability } \\
\text { Reporting (Laporan } \\
\text { Berkelanjutan). } \\
\end{array}$ & 389 & 0,517 & & 4,22 \\
\hline & \multirow[t]{5}{*}{ Lingkungan } & & & & & 3,76 \\
\hline & & $\begin{array}{l}\text { Perusahaan menggunakan } \\
\text { teknologi ramah } \\
\text { lingkungan. }\end{array}$ & 389 & 0,624 & & 3,8 \\
\hline & & $\begin{array}{l}\text { Perusahaan menerapkan } \\
\text { desain produk dan layanan } \\
\text { yang berorientasi pada } \\
\text { lingkungan (Go-Green). }\end{array}$ & 389 & 0,6 & & 3,57 \\
\hline & & $\begin{array}{l}\text { Perusahaan menggunakan } \\
\text { fasilitas dan infrastruktur } \\
\text { secara efisien. }\end{array}$ & 389 & 0,569 & & 3,98 \\
\hline & & $\begin{array}{l}\text { Perusahaan } \\
\text { mempertimbangkan } \\
\text { dampak lingkungan dari } \\
\text { penggunaan transportasi } \\
\text { dalam kegiatan } \\
\text { perusahaan. }\end{array}$ & 389 & 0,581 & & 3,66 \\
\hline & \multirow[t]{2}{*}{ Sosial } & & & & & 4,25 \\
\hline & & $\begin{array}{l}\text { Perusahaan } \\
\text { menyelenggarakan Good } \\
\text { Corporate Governance } \\
\text { (Tata Kelola Perusahaan }\end{array}$ & 389 & 0,72 & & 4,12 \\
\hline
\end{tabular}




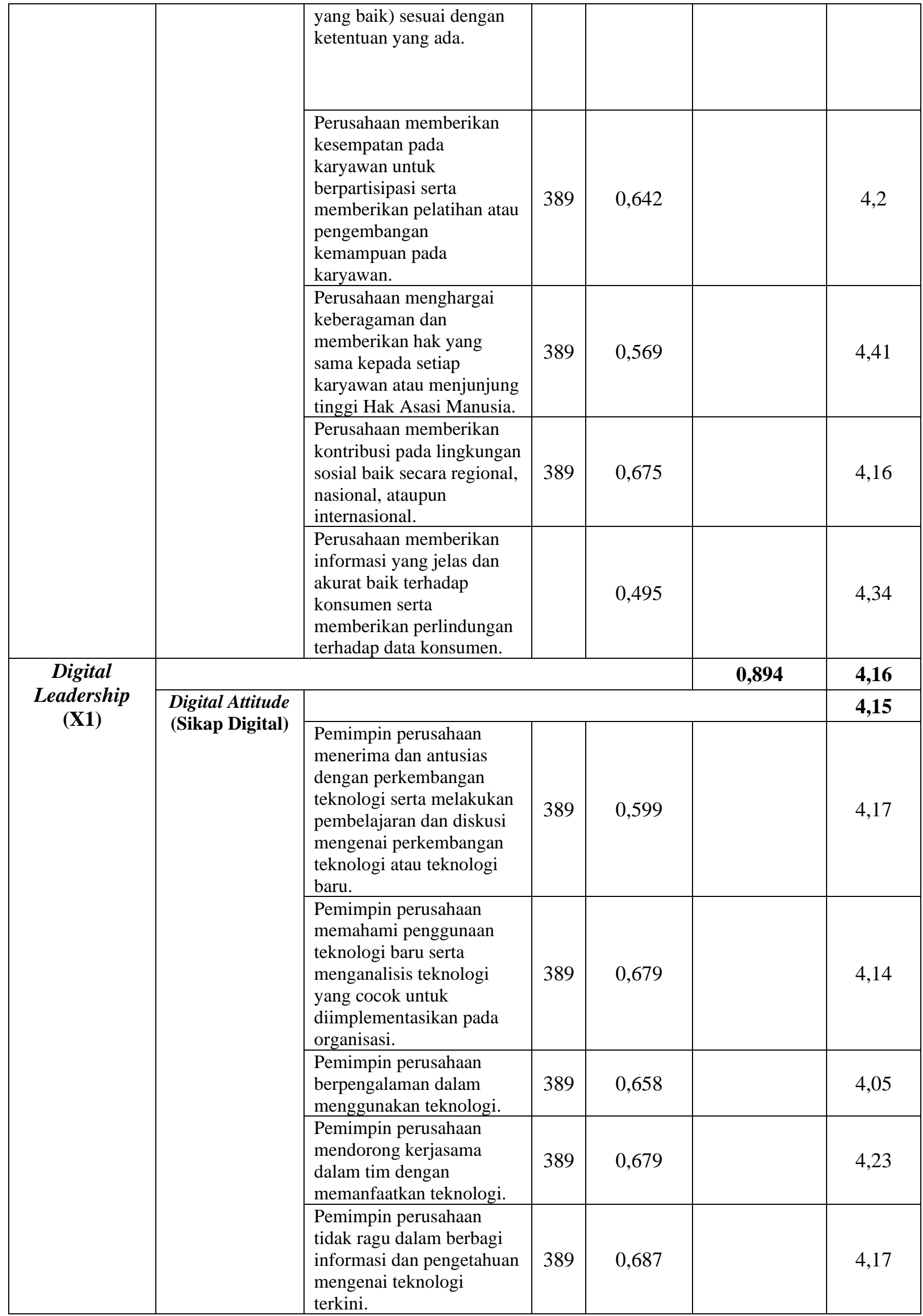




\begin{tabular}{|c|c|c|c|c|c|c|}
\hline & \multirow{6}{*}{$\begin{array}{c}\text { Leadership } \\
\text { Skill } \\
\text { (Kemampuan } \\
\text { Kepemimpinan } \\
\text { ) }\end{array}$} & & & & & \multirow{2}{*}{$\begin{array}{r}\mathbf{4 , 1 7} \\
4,34\end{array}$} \\
\hline & & $\begin{array}{l}\text { Pemimpin merumuskan } \\
\text { dan mengkomunikasikan } \\
\text { visi dan misi dalam } \\
\text { perusahaan. }\end{array}$ & 389 & 0,669 & & \\
\hline & & $\begin{array}{l}\text { Pemimpin mengambil } \\
\text { keputusan berdasarkan } \\
\text { data yang dimiliki serta } \\
\text { memiliki orientasi } \\
\text { terhadap pelanggan. }\end{array}$ & 389 & 0,585 & & 4,32 \\
\hline & & $\begin{array}{l}\text { Pemimpin merasa nyaman } \\
\text { dalam ketidakmenentuan } \\
\text { di era digital. }\end{array}$ & 389 & 0,515 & & 3,85 \\
\hline & & $\begin{array}{l}\text { Pemimpin menjadi role } \\
\text { model atau panutan bagi } \\
\text { bawahannya. }\end{array}$ & 389 & 0,659 & & 4,13 \\
\hline & & $\begin{array}{l}\text { Pemimpin } \\
\text { mempertahankan dan } \\
\text { mengelola karyawannya } \\
\text { dengan baik. }\end{array}$ & 389 & 0,66 & & 4,22 \\
\hline \multirow{11}{*}{$\begin{array}{l}\text { Total Quality } \\
\text { Management } \\
\quad \text { (X2) }\end{array}$} & \multirow{6}{*}{$\begin{array}{l}\text { Komitmen } \\
\text { Manajemen } \\
\text { Puncak }\end{array}$} & & & & 0,943 & 4,19 \\
\hline & & & & & & 4,32 \\
\hline & & $\begin{array}{l}\text { Perusahaan menganggap } \\
\text { kualitas merupakan } \\
\text { prioritas utama. }\end{array}$ & 389 & 0,524 & & 4,4 \\
\hline & & $\begin{array}{l}\text { Perusahaan memilih } \\
\text { manajemen dan kepala } \\
\text { departemen dan karyawan } \\
\text { berdasarkan kualitas } \\
\text { kinerja yang dimiliki. }\end{array}$ & 389 & 0,675 & & 4,31 \\
\hline & & $\begin{array}{l}\text { Perusahaan memberikan } \\
\text { promosi dan evaluasi } \\
\text { berdasarkan standar } \\
\text { kualitas yang telah } \\
\text { ditentukan. }\end{array}$ & 389 & 0,689 & & 4,31 \\
\hline & & $\begin{array}{l}\text { Perusahaan berkomitmen } \\
\text { untuk mendapatkan, } \\
\text { mempertahankan, dan } \\
\text { meningkatkan kualitas } \\
\text { pelatihan secara } \\
\text { berkelanjutan. }\end{array}$ & 389 & 0,732 & & 4,27 \\
\hline & \multirow{4}{*}{$\begin{array}{c}\text { Keterlibatan } \\
\text { Karyawan }\end{array}$} & & & & & 4,11 \\
\hline & & $\begin{array}{l}\text { Perusahaan melibatkan } \\
\text { karyawan dalam } \\
\text { pengambilan keputusan. }\end{array}$ & 389 & 0,612 & & 4,00 \\
\hline & & $\begin{array}{l}\text { Perusahaan mendorong } \\
\text { kerjasama karyawan di tim } \\
\text { baik satu divisi ataupun } \\
\text { antar departemen. }\end{array}$ & 389 & 0,677 & & 4,21 \\
\hline & & $\begin{array}{l}\text { Perusahaan memberikan } \\
\text { semangat, motivasi, dan } \\
\text { komitmen kepada } \\
\text { karyawan. }\end{array}$ & 389 & 0,703 & & 4,11 \\
\hline & & & & & & 4,21 \\
\hline
\end{tabular}




\begin{tabular}{|c|c|c|c|c|c|c|}
\hline & \multirow{4}{*}{$\begin{array}{l}\text { Kepuasan } \\
\text { Pelanggan }\end{array}$} & $\begin{array}{l}\text { Perusahaan tertarik } \\
\text { mengetahui kebutuhan dan } \\
\text { harapan pelanggan atau } \\
\text { klien. }\end{array}$ & 389 & 0,63 & & 4,22 \\
\hline & & $\begin{array}{l}\text { Perusahaan memberikan } \\
\text { respon yang cepat atas } \\
\text { pertanyaan pelanggan atau } \\
\text { klien. }\end{array}$ & 389 & 0,623 & & 4,20 \\
\hline & & $\begin{array}{l}\text { Perusahaan merancang } \\
\text { proses kegiatan organisasi } \\
\text { sesuai dengan kebutuhan } \\
\text { pelanggan atau klien. }\end{array}$ & 389 & 0,739 & & 4,22 \\
\hline & & $\begin{array}{l}\text { Perusahaan melakukan } \\
\text { inovasi atau layanan baru } \\
\text { untuk kepuasan pelanggan } \\
\text { atau klien. }\end{array}$ & 389 & 0,645 & & 4,20 \\
\hline & \multirow{3}{*}{$\begin{array}{l}\text { Kerja Sama } \\
\text { Tim }\end{array}$} & & & & & 4,05 \\
\hline & & $\begin{array}{l}\text { Karyawan melakukan } \\
\text { kerjasama antar tim dan } \\
\text { departemen serta } \\
\text { koordinasi untuk } \\
\text { meningkatkan kualitas. } \\
\end{array}$ & 389 & 0,683 & & 4,22 \\
\hline & & $\begin{array}{l}\text { Perusahaan mengutamakan } \\
\text { pemberian apresiasi secara } \\
\text { tim dibandingkan secara } \\
\text { individu. }\end{array}$ & 389 & 0,585 & & 3,88 \\
\hline & \multirow[t]{3}{*}{ Proses } & & & & & 4,13 \\
\hline & & $\begin{array}{l}\text { Perusahaan memiliki } \\
\text { sistem yang efektif dan } \\
\text { efisien untuk proses } \\
\text { kegiatan organisasi. }\end{array}$ & 389 & 0,759 & & 4,06 \\
\hline & & $\begin{array}{l}\text { Perusahaan mendesain } \\
\text { sistem untuk memenuhi } \\
\text { standar kualitas yang telah } \\
\text { ditetapkan perusahaan. }\end{array}$ & 389 & 0,727 & & 4,21 \\
\hline & \multirow{4}{*}{$\begin{array}{c}\text { Perbaikan } \\
\text { Berkelanjutan }\end{array}$} & & & & & 4,21 \\
\hline & & $\begin{array}{l}\text { Perusahaan mendukung } \\
\text { proses perbaikan jangka } \\
\text { Panjang. }\end{array}$ & 389 & 0,683 & & 4,21 \\
\hline & & $\begin{array}{l}\text { Perusahaan menyediakan } \\
\text { sumber daya untuk } \\
\text { perbaikan secara } \\
\text { berkelanjutan. }\end{array}$ & 389 & 0,693 & & 4,18 \\
\hline & & $\begin{array}{l}\text { Perusahaan mengelola } \\
\text { perbaikan secara } \\
\text { berkelanjutan melalui } \\
\text { kerjasama tim. }\end{array}$ & 389 & 0,743 & & 4,24 \\
\hline \multirow{4}{*}{$\begin{array}{l}\text { Knowledge } \\
\text { Management } \\
\text { (X3) }\end{array}$} & \multirow{4}{*}{$\begin{array}{c}\text { Knowledge } \\
\text { Creation/ } \\
\text { Capture } \\
\text { (Penciptaan } \\
\text { Pengetahuan) }\end{array}$} & & & & 0,925 & 4,16 \\
\hline & & & & & & 4,10 \\
\hline & & $\begin{array}{l}\text { Perusahaan menciptakan } \\
\text { pengetahuan atau ide baru } \\
\text { berdasarkan pengetahuan } \\
\text { lama. }\end{array}$ & 389 & 0,491 & & 4,29 \\
\hline & & $\begin{array}{l}\text { Perusahaan } \\
\text { mengumpulkan atau } \\
\text { memperoleh informasi dari } \\
\text { pihak lain. }\end{array}$ & 389 & 0,504 & & 4,19 \\
\hline
\end{tabular}




\begin{tabular}{|c|c|c|c|c|}
\hline & $\begin{array}{l}\text { Perusahaan memberikan } \\
\text { reward bagi karyawan } \\
\text { yang mampu memberikan } \\
\text { ide baru. }\end{array}$ & 389 & 0,626 & 3,89 \\
\hline & $\begin{array}{l}\text { Terdapat kegiatan } \\
\text { brainstorming atau diskusi } \\
\text { bersama dalam } \\
\text { perusahaan. }\end{array}$ & 389 & 0,701 & 4,03 \\
\hline \multirow{4}{*}{$\begin{array}{c}\text { Knowledge } \\
\text { Storage } \\
\text { (Penyimpanan } \\
\text { Pengetahuan) }\end{array}$} & & & & 4,23 \\
\hline & $\begin{array}{l}\text { Perusahaan menekankan } \\
\text { metode yang efektif dalam } \\
\text { penyimpanan data. }\end{array}$ & 389 & 0,695 & 4,14 \\
\hline & $\begin{array}{l}\text { Perusahaan menyimpan } \\
\text { data yang berkualitas. }\end{array}$ & 389 & 0,625 & 4,25 \\
\hline & $\begin{array}{l}\text { Perusahaan menyimpan } \\
\text { data yang jelas dan dapat } \\
\text { dipertanggungjawabkan. }\end{array}$ & 389 & 0,623 & 4,31 \\
\hline \multirow{5}{*}{$\begin{array}{c}\text { Knowledge } \\
\text { Transfer/ } \\
\text { Sharing } \\
\text { (Pendistribusia } \\
\text { n Pengetahuan) }\end{array}$} & & & & 4,16 \\
\hline & $\begin{array}{l}\text { Perusahaan mengadakan } \\
\text { program pelatihan atau } \\
\text { acara sesuai dengan } \\
\text { kebutuhan karyawan. }\end{array}$ & 389 & 0,646 & 4,11 \\
\hline & $\begin{array}{l}\text { Perusahaan menyediakan } \\
\text { fasilitas untuk melakukan } \\
\text { kolaborasi. }\end{array}$ & 389 & 0,69 & 4,06 \\
\hline & $\begin{array}{l}\text { Perusahaan mendorong } \\
\text { kerjasama tim dalam } \\
\text { pengerjaan project dan } \\
\text { penyelesaian masalah. }\end{array}$ & 389 & 0,718 & 4,23 \\
\hline & $\begin{array}{l}\text { Perusahaan memberikan } \\
\text { kemudahan fasilitas untuk } \\
\text { akses informasi. }\end{array}$ & 389 & 0,733 & 4,25 \\
\hline \multirow{5}{*}{$\begin{array}{c}\text { Knowledge } \\
\text { Application } \\
\text { (Pengaplikasia } \\
\text { n Pengetahuan) }\end{array}$} & & & & 4,18 \\
\hline & $\begin{array}{l}\text { Perusahaan merespon } \\
\text { secara cepat terhadap } \\
\text { kebutuhan pelanggan atau } \\
\text { klien. }\end{array}$ & 389 & 0,63 & 4,16 \\
\hline & $\begin{array}{l}\text { Perusahaan merespon } \\
\text { secara cepat terhadap } \\
\text { perubahan teknologi. }\end{array}$ & 389 & 0,686 & 4,09 \\
\hline & $\begin{array}{l}\text { Perusahaan bersikap } \\
\text { fleksibel dan siap akan } \\
\text { adanya perubahan }\end{array}$ & 389 & 0,633 & 4,13 \\
\hline & $\begin{array}{l}\text { Perusahaan melakukan } \\
\text { review dan evaluasi dari } \\
\text { setiap tindakan atau } \\
\text { kegiatan yang telah } \\
\text { dilakukan. }\end{array}$ & 389 & 0,695 & 4,33 \\
\hline
\end{tabular}

- Validitas dan Reliabilitas

Berdasarkan hasil pengujian pada tabel diatas, diketahui bahwa seluruh butir pertanyaan variabel memiliki nilai validitas ( $R$ hitung) yang lebih besar dari nilai $R$ tabel yaitu 0,08 , maka seluruh butir pertanyaan adalah valid. Setelah pengujian validitas, peneliti melakukan uji reliabilitas dan diperoleh hasil nilai reliabilitas untuk masing-masing variabel bernilai lebih besar dari 0,7. Oleh karena itu, dapat disimpulkan bahwa variabel Digital Leadership, Total Quality Management, Knowledge Management, dan Sustainability Management reliabel. 
- Variabel Sustainability Management

Pengukuran terhadap sustainability management pada perusahaan di DKI Jakarta menunjukkan nilai rata-rata 4,06 seperti yang tertera pada Tabel 2. Bila ditelaah lebih rinci berdasarkan dimensinya, dapat dilihat bahwa tingkat sustainability management tinggi pada dimensi ekonomi dengan nilai rata-rata sebesar 4,11 dan pada dimensi lingkungan dengan nilai rata-rata sebesar 3,76. Serta memiliki tingkat yang sangat tinggi pada dimensi sosial dengan nilai ratarata sebesar 4,25 .

- Variabel Digital Leadership

Pengukuran terhadap digital leadership pada perusahaan di DKI Jakarta menunjukkan nilai rata-rata sebesar 4,16 seperti yang tertera pada Tabel 2. Bila ditelaah lebih rinci berdasarkan dimensinya, dapat dilihat bahwa tingkat digital leadership tinggi pada dimensi digital attitude dengan nilai rata-rata sebesar 4,15 dan leadership skill dengan nilai rata-rata sebesar 4,17.

- Variabel Total Quality Management

Pengukuran terhadap total quality management pada perusahaan di DKI Jakarta menunjukkan nilai rata-rata 4,19 dengan deviasi baku 0,56 seperti yang tertera pada Tabel 2. Bila ditelaah lebih rinci berdasarkan dimensinya, dapat dilihat bahwa tingkat total quality management yang sangat tinggi pada dimensi komitmen manajemen puncak dengan nilai rata-rata sebesar 4,32, kepuasan pelanggan dengan nilai rata-rata sebesar 4,21, dan perbaikan berkelanjutan dengan nilai rata-rata sebesar 4,21. Serta berada pada kategori tinggi untuk dimensi keterlibatan karyawan dengan nilai rata-rata sebesar 4,11, kerjasama tim dengan nilai rata-rata sebesar 4,05, dan proses dengan nilai rata-rata sebesar 4,14.

- Variabel Knowledge Management

Pengukuran terhadap knowledge management pada perusahaan di DKI Jakarta menunjukkan nilai rata-rata 4,16 seperti yang tertera pada Tabel 4.15. Bila ditelaah lebih rinci berdasarkan dimensinya, dapat dilihat bahwa tingkat knowledge management tinggi pada dimensi knowledge storage dengan nilai rata-rata sebesar 4,23; dimensi knowledge creation/capture dengan nilai rata-rata sebesar 4,10; dimensi knowledge transfer/sharing dengan nilai rata-rata sebesar 4,16; dan dimensi knowledge application dengan nilai rata-rata sebesar 4,18.

\section{Uji Tabulasi Silang Variabel}

Berdasarkan Sumber Data

Tabel 3. Hasil Tabulasi Silang Berdasarkan Sumber Data

\begin{tabular}{|l|l|l|l|l|}
\hline Variabel & Sig & t hitung & t tabel & Keterangan \\
\hline Sustainability Management & 0,000 & 8,011 & 1,65 & Signifikan \\
\hline Digital Leadership & 0,000 & 4,371 & 1,65 & Signifikan \\
\hline Total Quality Management & 0,007 & 2,693 & 1,65 & Signifikan \\
\hline Knowledge Management & 0,000 & 4,407 & 1,65 & Signifikan \\
\hline
\end{tabular}

Sumber: Peneliti (2021)

Berdasarkan hasil perhitungan tabulasi silang jika dibedakan berdasarkan jenis kelamin dengan menggunakan uji independent sample t-test, diperoleh nilai sig yang lebih kecil dari nilai $\alpha$ sebesar 0,05 . Selain itu, diperoleh nilai t hitung yang lebih besar dari nilai t tabel sebesar 1,65. Maka dapat disimpulkan bahwa terdapat perbedaan antara sumber data terhadap variabel Sustainability Management, Digital leadership, Total Quality Management, dan Knowledge Management. 
Berdasarkan Jenis Kelamin

Tabel 4. Hasil Tabulasi Silang Berdasarkan Jenis Kelamin

\begin{tabular}{|l|l|l|l|l|}
\hline Variabel & Sig & t hitung & $\mathbf{t}$ tabel & Keterangan \\
\hline Sustainability Management & 0,307 & 1,202 & 1,65 & Tidak Signifikan \\
\hline Digital Leadership & 0,231 & 1,201 & 1,65 & Tidak Signifikan \\
\hline Total Quality Management & 0,519 & 0,645 & 1,65 & Tidak Signifikan \\
\hline Knowledge Management & 0,177 & 1,352 & 1,65 & Tidak Signifikan \\
\hline
\end{tabular}

Sumber: Peneliti (2021)

Berdasarkan hasil perhitungan tabulasi silang jika dibedakan berdasarkan jenis kelamin dengan menggunakan uji independent sample t-test, maka diperoleh nilai sig yang lebih besar dari nilai $\alpha$ sebesar 0,05. Selain itu, diperoleh nilai t hitung yang lebih kecil dari nilai t tabel sebesar 1,65. Maka dapat disimpulkan bahwa tidak terdapat perbedaan antara jenis kelamin terhadap variabel Sustainability Management, Digital leadership, Total Quality Management, dan Knowledge Management.

Berdasarkan Usia

Tabel 5. Hasil Tabulasi Silang Berdasarkan Usia

\begin{tabular}{|l|l|l|l|l|}
\hline Variabel & Sig & $\mathbf{X}^{2}$ hitung & $\mathbf{X}^{2}$ tabel & Keterangan \\
\hline Sustainability Management & 0,000 & 41,679 & 9.49 & Signifikan \\
\hline Digital Leadership & 0,016 & 12,262 & 9.49 & Signifikan \\
\hline Total Quality Management & 0,279 & 5,085 & 9.49 & Tidak Signifikan \\
\hline Knowledge Management & 0,011 & 13,104 & 9.49 & Signifikan \\
\hline
\end{tabular}

Sumber: Peneliti (2021)

Berdasarkan hasil perhitungan tabulasi silang jika dibedakan berdasarkan usia dengan menggunakan uji Kruskal-Wallis, maka diperoleh nilai sig yang lebih kecil dari nilai $\alpha$ sebesar 0,05 . Sedangkan untuk variabel Total Quality Management diperoleh nilai sig sebesar 0,279 lebih besar dari nilai $\alpha$ sebesar 0,05 . Selain itu, diperoleh nilai $\mathrm{X}^{2}$ hitung untuk variabel Sustainability Management sebesar 41,679, Digital Leadership sebesar 12,262, dan Knowledge Management sebesar 13,104 yang lebih besar dari nilai $\mathrm{X}^{2}$ tabel sebesar 9,49. Sedangkan untuk variabel Total Quality Management diperoleh nilai X ${ }^{2}$ sebesar 2,693 yang lebih kecil dari nilai $X^{2}$ tabel sebesar 9,49. Maka dapat disimpulkan bahwa terdapat perbedaan antara usia terhadap Sustainability Management, Digital leadership, dan Knowledge Management, sedangkan tidak terdapat perbedaan antara Usia terhadap Total Quality Management.

Berdasarkan Pendidikan Terakhir

Tabel 6. Hasil Tabulasi Silang Berdasarkan Pendidikan Terakhir

\begin{tabular}{|l|l|l|l|l|}
\hline Variabel & Sig & $\mathbf{X}^{\mathbf{2}}$ hitung & $\mathbf{X}^{2}$ tabel & Keterangan \\
\hline Sustainability Management & 0,000 & 22,206 & 9,49 & Signifikan \\
\hline Digital Leadership & 0,042 & 9,914 & 9,49 & Signifikan \\
\hline Total Quality Management & 0,553 & 3,026 & 9,49 & Tidak Signifikan \\
\hline Knowledge Management & 0,157 & 6,631 & 9,49 & Tidak Signifikan \\
\hline
\end{tabular}

Sumber: Peneliti (2021)

Berdasarkan hasil perhtiungan tabulasi silang jika dibedakan berdasarkan pendidikan terakhir dengan menggunakan uji Kruskal-Wallis, maka diperoleh nilai sig untuk variabel Sustainability Management sebesar 0,000 dan Digital Leadership sebesar 0,000 yang lebih kecil dari nilai a sebesar 0,05. Sedangkan untuk variabel Total Quality Management diperoleh nilai sig sebesar 0,553 dan Knowledge Management sebesar 0,157 yang lebih besar dari nilai $\alpha$ sebesar 0,05 . Selain itu diperoleh nilai $\mathrm{X}^{2}$ hitung untuk variabel Sustainability Management sebesar 22,206 dan Digital Leadership sebesar 9,914 yang lebih besar dari $\mathrm{X}^{2}$ tabel sebesar 9,49. Sedangkan untuk variabel Total Quality Management diperoleh nilai $\mathrm{X}^{2}$ hitung sebesar 3,026 dan Knowledge Management sebesar 6,631 yang lebih kecil dari $\mathrm{X}^{2}$ tabel 
sebesar 9,49. Maka dapat disimpulkan bahwa terdapat perbedaan antara pendidikan terakhir terhadap Sustainability Management dan Digital Leadership, sedangkan tidak terdapat perbedaan antara pendidikan terakhir terhadap variabel Total Quality Management dan Knowledge Management.

Berdasarkan Jenis Organisasi

Tabel 7. Hasil Tabulasi Silang Berdasarkan Jenis Organisasi

\begin{tabular}{|l|l|l|l|l|}
\hline Variabel & Sig & $\mathbf{t}$ hitung & $\mathbf{t}$ tabel & Keterangan \\
\hline Sustainability Management & 0,000 & 8,244 & 1,65 & Signifkan \\
\hline Digital Leadership & 0,000 & 4,297 & 1,65 & Signifkan \\
\hline Total Quality Management & 0,004 & 2,907 & 1,65 & Signifkan \\
\hline Knowledge Management & 0,000 & 4,520 & 1,65 & Signifkan \\
\hline
\end{tabular}

Sumber: Peneliti (2021)

Berdasarkan hasil perhitungan tabulasi silang jika dibedakan berdasarkan jenis organisasi dengan menggunakan uji independent sample t-test, maka diperoleh nilai sig yang lebih besar dari nilai $\alpha$ sebesar 0,05. Selain itu, diperoleh nilai t hitung yang lebih kecil dari nilai t tabel sebesar 1,65. Maka dapat disimpulkan bahwa tidak terdapat perbedaan antara jenis organisasi terhadap Sustainability Management, Digital leadership, Total Quality Management, dan Knowledge Management.

Berdasarkan Lama Bekerja

Tabel 8. Hasil Tabulasi Silang Berdasarkan Lama Bekerja

\begin{tabular}{|l|l|l|l|l|}
\hline Variabel & Sig & $\mathbf{X}^{\mathbf{2}}$ hitung & $\mathbf{X}^{\mathbf{2}}$ tabel & Keterangan \\
\hline Sustainability Management & 0,000 & 20,825 & 7,81 & Signifikan \\
\hline Digital Leadership & 0,200 & 4,646 & 7,81 & Tidak Signifikan \\
\hline Total Quality Management & 0,135 & 5,555 & 7,81 & Tidak Signifikan \\
\hline Knowledge Management & 0,017 & 10,188 & 7,81 & Signifikan \\
\hline
\end{tabular}

Sumber: Peneliti (2021)

Berdasarkan hasil perhtiungan tabulasi silang jika dibedakan berdasarkan lama bekerja dengan menggunakan uji Kruskal-Wallis, maka diperoleh nilai sig untuk variabel Sustainability Management sebesar 0,000 dan Knowledge Management sebesar 0,017 yang lebih kecil dari nilai $\alpha$ sebesar 0,05. Sedangkan untuk variabel Digital Leadership diperoleh nilai sig sebesar 0,200 dan Total Quality Management sebesar 0,135 yang lebih besar dari nilai $\alpha$ sebesar 0,05 . Selain itu diperoleh nilai $X^{2}$ hitung untuk variabel Sustainability Management sebesar 20,825 dan Knowledge Management sebesar 10,188 yang lebih besar dari $\mathrm{X}^{2}$ tabel sebesar 7,81. Sedangkan untuk variabel Digital Leadership diperoleh nilai $X^{2}$ hitung sebesar 4,646 dan Total Quality Management sebesar 5,555 yang lebih kecil dari $\mathrm{X}^{2}$ tabel sebesar 7,81. Maka dapat disimpulkan bahwa terdapat perbedaan antara lama bekerja terhadap Sustainability Management dan Knowledge Managemenent, sedangkan tidak terdapat perbedaan antara lama bekerja terhadap variabel Digital Leadership Total Quality Management.

Berdasarkan Posisi atau Jabatan

Tabel 9. Hasil Tabulasi Silang Berdasarkan Posisi atau Jabatan

\begin{tabular}{|l|l|l|l|l|}
\hline Variabel & Sig & $\mathbf{X}^{\mathbf{2}}$ hitung & $\mathbf{X}^{\mathbf{2}}$ tabel & Keterangan \\
\hline Sustainability Management & 0,000 & 50,534 & 14,07 & Signifikan \\
\hline Digital Leadership & 0,025 & 16,054 & 14,07 & Signifikan \\
\hline Total Quality Management & 0,122 & 11,391 & 14,07 & Tidak Signifikan \\
\hline Knowledge Management & 0,016 & 17,262 & 14,07 & Signifikan \\
\hline
\end{tabular}

Sumber: Peneliti (2021)

Berdasarkan hasil perhitungan tabulasi silang jika dibedakan berdasarkan posisi/jabatan dengan menggunakan uji Kruskal-Wallis, maka diperoleh nilai sig untuk variabel Sustainability Management 
sebesar 0,000, Digital Leadership sebesar 0,025, dan Knowledge Management sebesar 0,016 yang lebih kecil dari nilai $\alpha$ sebesar 0,05 . Sedangkan untuk variabel Total Quality Management diperoleh nilai sig sebesar 0,122 lebih besar dari nilai $\alpha$ sebesar 0,05 . Selain itu, diperoleh nilai $\mathrm{X}^{2}$ hitung untuk variabel Sustainability Management sebesar 50,354, Digital Leadership sebesar 16,054, dan Knowledge Management sebesar 17,262 yang lebih besar dari nilai $\mathrm{X}^{2}$ tabel sebesar 14,07. Sedangkan untuk variabel Total Quality Management diperoleh nilai $\mathrm{X}^{2}$ sebesar 11,391 yang lebih kecil dari nilai $\mathrm{X}^{2}$ tabel sebesar 14,07. Maka dapat disimpulkan bahwa terdapat perbedaan antara posisi/jabatan terhadap Sustainability Management, Digital leadership, dan Knowledge Management, sedangkan tidak terdapat perbedaan antara posisi/jabatan terhadap Total Quality Management.

Berdasarkan Jenis Industri

Tabel 10. Hasil Tabulasi Silang Berdasarkan Jenis Industri

\begin{tabular}{|l|l|l|l|l|}
\hline Variabel & Sig & $\mathbf{X}^{\mathbf{2}}$ hitung & $\mathbf{X}^{\mathbf{2}}$ tabel & Keterangan \\
\hline Sustainability Management & 0,000 & 55,154 & 19,68 & Signifikan \\
\hline Digital Leadership & 0,004 & 27,214 & 19,68 & Signifikan \\
\hline Total Quality Management & 0,377 & 11,822 & 19,68 & Tidak Signifikan \\
\hline Knowledge Management & 0,017 & 23,189 & 19,68 & Signifikan \\
\hline
\end{tabular}

Sumber: Peneliti (2021)

Berdasarkan hasil perhitungan tabulasi silang jika dibedakan berdasarkan jenis industri dengan menggunakan uji Kruskal-Wallis, maka diperoleh nilai sig untuk variabel Sustainability Management sebesar 0,000, Digital Leadership sebesar 0,004, dan Knowledge Management sebesar 0,017yang lebih kecil dari nilai $\alpha$ sebesar 0,05. Sedangkan untuk variabel Total Quality Management diperoleh nilai sig sebesar 0,377 lebih besar dari nilai $\alpha$ sebesar 0,05 . Selain itu, diperoleh nilai $\mathrm{X}^{2}$ hitung untuk variabel Sustainability Management sebesar 55,154, Digital Leadership sebesar 27,214, dan Knowledge Management sebesar 23.189 yang lebih besar dari nilai $\mathrm{X}^{2}$ tabel sebesar 14,07. Sedangkan untuk variabel Total Quality Management diperoleh nilai $\mathrm{X}^{2}$ sebesar 11,822 yang lebih kecil dari nilai $\mathrm{X}^{2}$ tabel sebesar 14,07. Maka dapat disimpulkan bahwa terdapat perbedaan antara jenis industri terhadap Sustainability Management, Digital leadership, dan Knowledge Management, sedangkan tidak terdapat perbedaan antara jenis industri terhadap Total Quality Management.

\section{Uji Hipotesis}

Uji Hipotesis $X_{1}, X_{2}$, dan $X_{3}$ Terhadap $Y$

- Koefisien Determinasi $\mathrm{X}_{1}, \mathrm{X}_{2}$, dan $\mathrm{X}_{3}$ Terhadap $\mathrm{Y}$

Tabel 11. Koefisien Determinasi X1, X2, dan X3 Terhadap Y

\section{Model Summary}

\begin{tabular}{|l|r|r|r|r|}
\hline Model & \multicolumn{1}{|c|}{ R } & R Square & $\begin{array}{c}\text { Adjusted R } \\
\text { Square }\end{array}$ & $\begin{array}{c}\text { Std. Error of } \\
\text { the Estimate }\end{array}$ \\
\hline 1 & $.777 \mathrm{a}$ & .604 & .601 & .36011 \\
\hline
\end{tabular}

a. Predictors: (Constant), Digital Leadership, Total Quality

\section{Management, Knowledge Management}

Berdasarkan hasil pengujian SPSS, didapatkan nilai koefisien determinasi (R square) sebesar 0,604. Hal ini menunjukkan bahwa sebesar 60,4\% variabel Digital Leadership, Total Quality Management, dan Knowledge Management dapat menjelaskan variasi variabel Sustainability Management. Sisanya sebesar 39,6\% dijelaskan oleh variabel lain yang tidak dibahas dalam penelitian ini. 
- Persamaan Regresi $\mathrm{X}_{1}, \mathrm{X}_{2}$, dan $\mathrm{X}_{3}$ Terhadap $\mathrm{Y}$

Tabel 12. Analisis Regresi X1, X2, dan X3 Terhadap Y

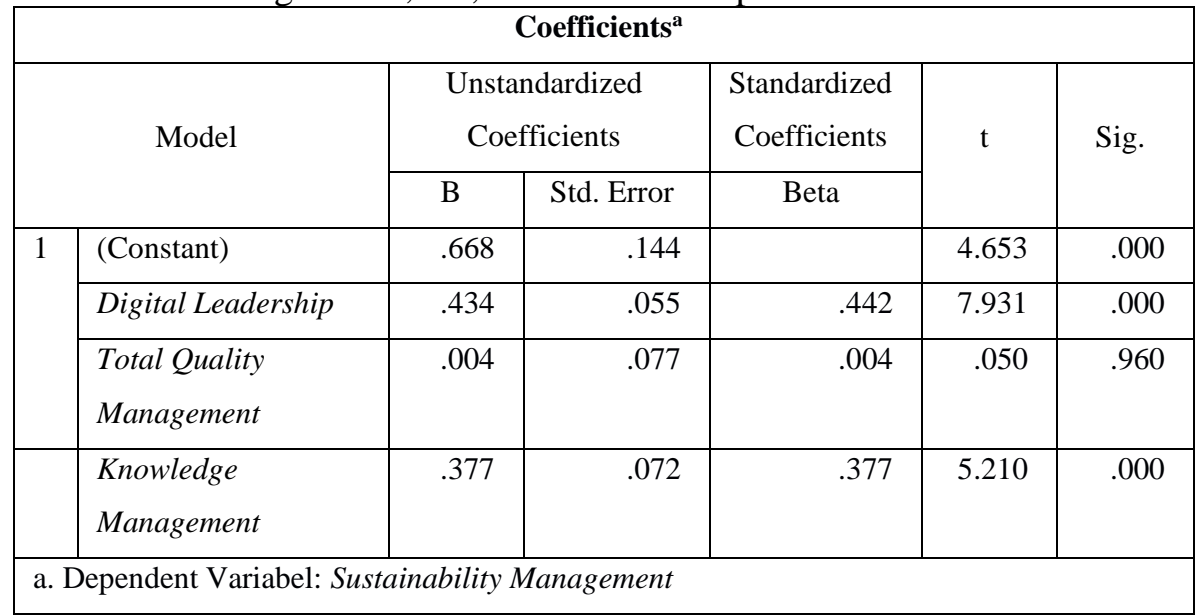

Berdasarkan hasil pengolahan pada tabel 12 didapatkan persamaan regresi sebagai berikut:

$$
Y=0,668+0,434 X_{1}+0,004 X_{2}+0,377 X_{3}+0,36011 e_{1}
$$

Dari persamaan regresi yang terbentuk di atas, dapat diinterpretasikan jika Sustainability Management (Y) akan bernilai sebesar 0,668 satuan apabila seluruh variabel bebasnya, yaitu Digital Leadership $\left(\mathrm{X}_{1}\right)$, Total Quality Management $\left(\mathrm{X}_{2}\right)$, dan Knowledge Management $\left(\mathrm{X}_{3}\right)$ dianggap konstan atau 0. Sustainability Management (Y) akan meningkat sebesar 0,434 satuan untuk setiap tambahan satu poin pada Digital Leadership $\left(\mathrm{X}_{1}\right)$, dengan asumsi variabel bebas lainnya dianggap konstan. Sustainability Management (Y) akan meningkat sebesar 0,004 satuan untuk setiap tambahan satu poin pada Total Quality Management $\left(\mathrm{X}_{2}\right)$, dengan asumsi variabel bebas lainnya dianggap konstan. Sustainability Management (Y) akan meningkat sebesar 0,377 satuan untuk setiap tambahan satu poin pada Knowledge Management $\left(\mathrm{X}_{3}\right)$, dengan asumsi variabel bebas lainnya dianggap konstan. Sustainability Management (Y) ditentukan oleh Digital Leadership $\left(\mathrm{X}_{1}\right)$ sebesar 0,434; Total Quality Management $\left(\mathrm{X}_{2}\right)$ sebesar 0,004; Knowledge Management $\left(\mathrm{X}_{3}\right)$ sebesar 0,377; dan sisanya 0,36011 dijelaskan oleh variabel lain yang tidak dibahas dalam penelitian ini.

- $\quad$ Uji t $\mathrm{X}_{1}, \mathrm{X}_{2}$, dan $\mathrm{X}_{3}$ Terhadap $\mathrm{Y}$

Dasar pengambilan keputusan:

$\mathrm{t}$ hitung $\leq \mathrm{t}$ tabel dan $\mathrm{Sig} \geq \alpha \rightarrow \mathrm{H}_{0}$ ditolak atau $\mathrm{H}_{\mathrm{a}}$ diterima

$\mathrm{t}$ hitung $<\mathrm{t}$ tabel dan Sig $<\alpha \rightarrow \mathrm{H}_{0}$ diterima atau $\mathrm{H}_{\mathrm{a}}$ ditolak

Tabel 13. Uji t X1, X2, dan X3 Terhadap Y

\begin{tabular}{|c|l|c|c|c|}
\hline Hipotesis & Uji Pengaruh & t hitung & Sig & Kesimpulan \\
\hline Hipotesis 1 & Digital Leadership $\rightarrow$ Sustainability Management & 7,931 & 0,000 & $\mathrm{H}_{0}$ Ditolak \\
\hline Hipotesis 4 & Total Quality Management $\rightarrow$ Sustainability Management & 0,050 & 0,960 & $\mathrm{H}_{0}$ Diterima \\
\hline Hipotesis 5 & Knowledge Management $\rightarrow$ Sustainability Management & 5,210 & 0,000 & $\mathrm{H}_{0}$ Ditolak \\
\hline
\end{tabular}

Hasil pengujian hipotesis secara parsial dengan menggunakan uji t menunjukkan bahwa:

> Hipotesis 1 dapat disimpulkan bahwa terdapat pengaruh signifikan antara Digital Leadership terhadap Sustainability Management, maka $\mathrm{H}_{1}$ diterima. 
$>$ Hipotesis 4 dapat disimpulkan bahwa tidak terdapat pengaruh antara Total Quality Management terhadap Sustainability Management, maka $\mathrm{H}_{4}$ ditolak.

$>$ Hipotesis 5 dapat disimpulkan bahwa terdapat pengaruh signifikan antara Knowledge Management terhadap Sustainability Management, maka $\mathrm{H}_{5}$ diterima.

Uji Hipotesis $X_{1}$ dan $X_{3}$ Terhadap $X_{2}$

- Koefisien Determinasi $X_{1}$ dan $X_{3}$ Terhadap $X_{2}$

Tabel 14. Koefisien Determinasi X1 dan X3 Terhadap X2

Model Summary

\begin{tabular}{|l|r|r|r|r|}
\hline Model & \multicolumn{1}{|c|}{$\mathrm{R}$} & R Square & $\begin{array}{c}\text { Adjusted R } \\
\text { Square }\end{array}$ & $\begin{array}{l}\text { Std. Error of } \\
\text { the Estimate }\end{array}$ \\
\hline 1 & $.906 \mathrm{a}$ & .821 & .821 & .23736 \\
\hline
\end{tabular}

a. Predictors: (Constant), Digital Leadership, Knowledge

Management

Berdasarkan hasil pengujian SPSS, didapatkan nilai koefisien determinasi (R square) sebesar 0,821. Hal ini menunjukkan bahwa sebesar $82,1 \%$ variabel Digital Leadership dan Knowledge Management dapat menjelaskan variasi variabel Total Quality Management. Sisanya sebesar $17,9 \%$ dijelaskan oleh variabel lain yang tidak dibahas dalam penelitian ini.

- Persamaan Regresi $X_{1}$ dan $X_{3}$ Terhadap $X_{2}$

Tabel 15. Analisis Regresi X1 dan X3 Terhadap X2

\begin{tabular}{|c|c|c|c|c|c|c|}
\hline \multicolumn{7}{|c|}{ Coefficients $^{\mathrm{a}}$} \\
\hline \multirow{2}{*}{\multicolumn{2}{|c|}{ Model }} & \multicolumn{2}{|c|}{$\begin{array}{c}\text { Unstandardized } \\
\text { Coefficients }\end{array}$} & \multirow{2}{*}{$\begin{array}{c}\text { Standardized } \\
\text { Coefficients }\end{array}$} & \multirow[t]{2}{*}{$\mathrm{t}$} & \multirow[t]{2}{*}{ Sig. } \\
\hline & & B & Std. Error & & & \\
\hline \multirow[t]{3}{*}{1} & (Constant) & 0.321 & 0.093 & & 3.448 & 0.001 \\
\hline & Digital Leadership & 0.272 & 0.033 & 0.282 & 8.183 & 0.000 \\
\hline & Knowledge Management & 0.658 & 0.034 & 0.668 & 19.358 & 0.000 \\
\hline
\end{tabular}

Berdasarkan hasil pengolahan pada tabel 15 didapatkan persamaan regresi sebagai berikut:

$$
Y=0,321+0,272 X_{1}+0,658 X_{3}+0,23736 e_{2}
$$

Dari persamaan regresi yang terbentuk di atas dapat diinterpretasikan jika Total Quality Management (Y) akan bernilai sebesar 0,321 satuan apabila seluruh variabel bebasnya, yaitu Digital Leadership $\left(\mathrm{X}_{1}\right)$ dan Knowledge Management $\left(\mathrm{X}_{3}\right)$ dianggap konstan atau 0. Total Quality Management (Y) akan meningkat sebesar 0,272 satuan untuk setiap tambahan satu poin pada Digital Leadership $\left(\mathrm{X}_{1}\right)$, dengan asumsi variabel bebas lainnya dianggap konstan. Total Quality Management (Y) akan meningkat sebesar 0,658 satuan untuk setiap tambahan satu poin pada Knowledge Management $\left(\mathrm{X}_{3}\right)$, dengan asumsi variabel bebas lainnya dianggap konstan. Total Quality Management (Y) ditentukan oleh Digital Leadership $\left(\mathrm{X}_{1}\right)$ sebesar 0,272; Knowledge Management $\left(\mathrm{X}_{3}\right)$ sebesar 0,658 dan sisanya 0,23736 dijelaskan oleh variabel lain yang tidak dibahas dalam penelitian ini. 
- Uji $\mathrm{X}_{1}$ dan $\mathrm{X}_{3}$ Terhadap $\mathrm{X}_{2}$

Dasar pengambilan keputusan:

t hitung $\leq \mathrm{t}$ tabel dan $\mathrm{Sig} \geq \alpha \rightarrow \mathrm{H}_{0}$ ditolak atau $\mathrm{H}_{\mathrm{a}}$ diterima

t hitung $<\mathrm{t}$ tabel dan $\mathrm{Sig}<\alpha \rightarrow \mathrm{H}_{0}$ diterima atau $\mathrm{H}_{\mathrm{a}}$ ditolak

Tabel 16. Uji t X1 dan X3 Terhadap X2

\begin{tabular}{|c|l|c|c|c|}
\hline Hipotesis & \multicolumn{1}{|c|}{ Uji Pengaruh } & t hitung & Sig & Kesimpulan \\
\hline Hipotesis 2 & Digital Leadership $\rightarrow$ Total Quality Management & 8,183 & 0,000 & $\mathrm{H}_{0}$ Ditolak \\
\hline Hipotesis 6 & Knowledge Management $\rightarrow$ Total Quality Management & 19,358 & 0,000 & $\mathrm{H}_{0}$ Ditolak \\
\hline
\end{tabular}

Hasil pengujian hipotesis secara parsial dengan menggunakan uji t menunjukkan bahwa:

$>$ Hipotesis 2 dapat disimpulkan bahwa terdapat pengaruh signifikan antara Digital Leadership terhadap Total Quality Management, maka $\mathrm{H}_{2}$ diterima.

$>$ Hipotesis 6 dapat disimpulkan bahwa terdapat pengaruh signifikan antara Knowledge Management terhadap Total Quality Management, maka $\mathrm{H}_{6}$ diterima.

\section{Uji Hipotesis $X_{1}$ Terhadap $X_{3}$}

- Koefisien Determinasi $X_{1}$ Terhadap $X_{3}$

Tabel 17. Koefisien Determinasi X1 Terhadap X3

\section{Model Summary}

\begin{tabular}{|l|r|r|r|r|}
\hline Model & \multicolumn{1}{|c|}{ R } & R Square & $\begin{array}{c}\text { Adjusted R } \\
\text { Square }\end{array}$ & $\begin{array}{l}\text { Std. Error of } \\
\text { the Estimate }\end{array}$ \\
\hline 1 & $.782 \mathrm{a}$ & .612 & .611 & .35522 \\
\hline
\end{tabular}

a. Predictors: (Constant), Digital Leadership

Berdasarkan hasil pengujian SPSS, didapatkan nilai koefisien determinasi (R square) sebesar 0,604. Hal ini menunjukkan bahwa sebesar 60,4\% variabel Digital Leadership, Total Quality Management, dan Knowledge Management dapat menjelaskan variasi variabel Sustainability Management. Sisanya sebesar 39,6\% dijelaskan oleh variabel lain yang tidak dibahas dalam penelitian ini.

- Persamaan Regresi $\mathrm{X}_{1}$ Terhadap $\mathrm{X}_{3}$

Tabel 18. Analisis Regresi X1 Terhadap X3

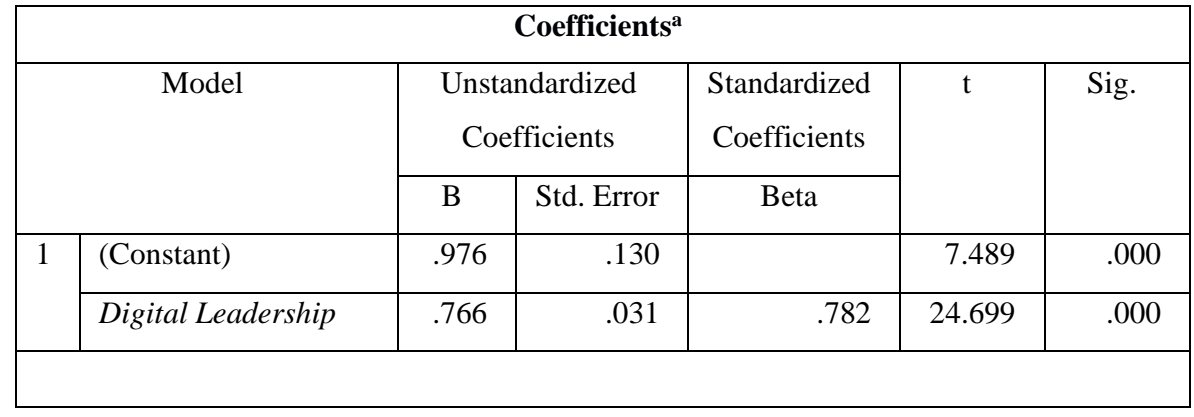

Berdasarkan hasil pengolahan pada tabel 18 didapatkan persamaan regresi sebagai berikut:

$$
\mathrm{Y}=0,976+0,766 \mathrm{X}_{1}+0,35522 \mathrm{e}_{3}
$$


Dari persamaan regresi yang terbentuk di atas dapat diinterpretasikan jika Knowledge Management (Y) akan bernilai sebesar 0,976 satuan apabila variabel bebasnya, yaitu Digital Leadership $\left(\mathrm{X}_{1}\right)$ dianggap konstan atau 0 . Knowledge Management $(\mathrm{Y})$ akan meningkat sebesar 0,766 satuan untuk setiap tambahan satu poin pada Digital Leadership $\left(\mathrm{X}_{1}\right)$. Knowledge Management $(\mathrm{Y})$ ditentukan oleh Digital Leadership $\left(\mathrm{X}_{1}\right)$ sebesar 0,766 dan sisanya 0,35522 $\mathrm{e}_{2}$ dijelaskan oleh variabel lain yang tidak dibahas dalam penelitian ini.

- Uji t $\mathrm{X}_{1}$ Terhadap $\mathrm{X}_{3}$

Dasar pengambilan keputusan:

$\mathrm{t}$ hitung $\leq \mathrm{t}$ tabel dan $\mathrm{Sig} \geq \alpha \rightarrow \mathrm{H}_{0}$ ditolak atau $\mathrm{H}_{\mathrm{a}}$ diterima

t hitung $<\mathrm{t}$ tabel dan $\mathrm{Sig}<\alpha \rightarrow \mathrm{H}_{0}$ diterima atau $\mathrm{H}_{\mathrm{a}}$ ditolak

Tabel 19. Uji t X1 Terhadap X3

\begin{tabular}{|c|c|c|c|c|}
\hline Hipotesis & Uji Pengaruh & t hitung & Sig & Kesimpulan \\
\hline Hipotesis 3 & Digital L eadership $\rightarrow$ Knowledge Management & 24,699 & 0,000 & $\mathrm{H}_{0}$ Ditolak \\
\hline
\end{tabular}

Hasil pengujian hipotesis secara parsial dengan menggunakan uji t menunjukkan bahwa:

$>$ Hipotesis 3 dapat disimpulkan bahwa terdapat pengaruh signifikan antara Digital Leaderhsip terhadap Knowledge Management, maka $\mathrm{H}_{3}$ diterima.

\section{Path Analysis (Analisis Jalur)}

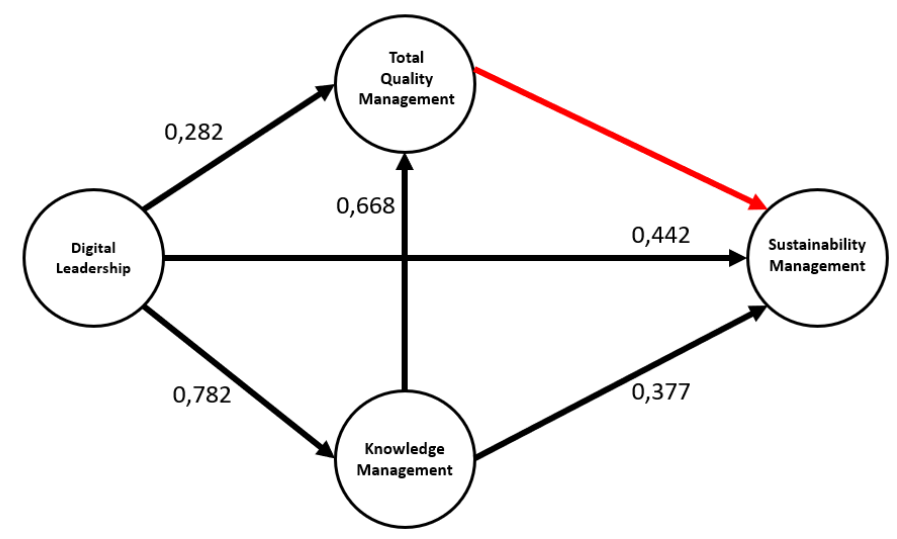

Gambar 2. Path Analysis

- Digital Leadership memiliki pengaruh signifikan terhadap Sustainability Management dengan nilai koefisien jalur sebesar 0,442 .

- Digital Leadership memiliki pengaruh signifikan terhadap Total Quality Management dengan nilai koefisien jalur sebesar 0,282 .

- Digital Leadership memiliki pengaruh signifikan terhadap Knowledge Management dengan nilai koefisien jalur sebesar 0,782 .

- Total Quality Management tidak memiliki pengaruh signifikan terhadap Sustainability Management. Sehingga keberadaan Total Quality Management pada Perusahaan di DKI Jakarta tidak berpengaruh terhadap Sustainability Management pada Perusahaan di DKI Jakarta

- Knowledge Management memiliki pengaruh signifikan terhadap Sustainability Management dengan nilai koefisien jalur sebesar 0,377.

- Knowledge Management memiliki pengaruh signifikan terhadap Total Quality Management dengan nilai koefisien jalur sebesar 0,668. 
- Knowledge Management tidak memainkan peran mediator antara Digital Leadership dan Sustainability Management dengan nilai koefisien jalur sebesar 0,294 yang lebih kecil daripada nilai koefisien jalur Digital Leadership langsung ke Sustainability Management.

- Knowledge Management memainkan peran mediator dalam hal pengaruh antara Digital Leadership terhadap Total Quality Management dengan nilai koefisien jalur sebesar 0,522 yang lebih besar daripada nilai koefisien jalur Digital Leadership langsung ke Total Quality Management.

- Sustainability Management dipengaruhi secara langsung oleh Digital Leadership dan Knowledge Management.

\section{Implikasi Hasil Penelitian}

\section{- Implikasi Teoritis}

Berdasarkan hasil penelitian yang diolah menggunakan SPSS dapat disimpulkan bahwa peranan pemimpin di dalam perusahaan untuk merumuskan dan mengomunikasikan visi dan misi berperan penting dalam pembentukan digital leadership di dalam perusahaan, hal tersebut dapat dilihat dari butir pertanyaan DL06 yaitu: "pemimpin merumuskan dan mengkomunikasikan visi dan misi dalam perusahaan" yang memperoleh nilai rata-rata tertinggi yaitu 4.34. Diperoleh juga hasil bahwa digital leadership berpengaruh secara signifikan terhadap sustainability management dan hasil penelitian tersebut sejalan dengan penelitian oleh Angelos Pantouvakis dan Ilias Vlachos pada tahun 2020 dengan judul "Talent and leadership effects on sustainable performance in the maritime industry" dan Katarzyna Szczepańska-Woszczyna, Joanna Kurowska-Pysz pada tahun 2016 dengan judul "Sustainable business development through leadership in SMEs". Diperoleh juga hasil bahwa digital leadership berpengaruh secara signifikan terhadap total quality management dan hasil penelitian tersebut sejalan dengan penelitian oleh Seyhan Teoman dan Füsun Ulengin pada tahun 2017 dengan judul "The Impact of Management Leadership on Qualiy Performance throughout a Supply Chain: An Empirical Study". Selain itu juga digital leadership berpengaruh secara signifikan terhadap knowledge management dan hasil penelitian tersebut sejalan dengan penelitian oleh Phong ba Le dan Hui Lei pada tahun 2017 dengan judul "How transformational leadership supports knowledge sharing: Evidence from Chinese manufacturing and service firms".

Dalam penelitan yang dilakukan oleh peneliti, ditemukan bahwa variabel Total Quality Management $\left(\mathrm{X}_{2}\right)$ memiliki pengaruh yang tidak signifikan terhadap variabel Sustainability Management (Y). Hasil dari penelitian ini dapat dikarenakan adanya kegagalan dalam penerapan Total Quality Management di dalam perusahaan. Seperti hasil penelitian yang dilakukan bahwa indikator TQM13 didapatkan dengan nilai rata-rata 3.88 dimana indikator ini memiliki nilai terkecil dibandingkan nilai indikator-indikator lainnya dan indikator ini membahas mengenai bagaimana perusahaan mengutamakan pemberian apresiasi secara tim dibandingkan secara individu. Dalam jurnalnya, G. Muruganantham, S. Vinodh, C.

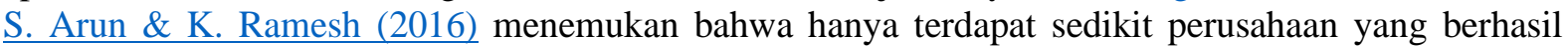
menerapkan cara pandang keseluruhan mengenai filosofi yang dimiliki oleh Total Quality Management. Mereka menemukan fakta bahwa perusahaan-perusahaan belum sepenuhnya menyadari manfaat dari segi keuangan dan non-keuangan dari penerapan Total Quality Management. Dalam penelitiannya ditemukan bahwa salah satu hal yang sering menjadi penyebab kegagalan dalam implementasi Total Quality Management adalah kurangnya program pengakuan serta penghargaan kepada karyawan yang dimana dalam penelitian tersebut variabel program pengakuan tergolong kedalam (Hambatan Sumber Daya Manusia) dengan frekuensi 110 kasus dari total 346 kasus selama 30 tahun kebelakang mulai dari tahun 1980 hingga 2010. Untuk itu dapat diduga bahwa terjadi kegagalan dalam implementasi Total Quality Management di perusahaan yang ditandai dengan hasil penelitian yang menunjukan bahwa kurangnya pemberian apresiasi yang dilakukan oleh perusahaan.

Berdasarkan hasil penelitian yang diolah menggunakan SPSS dapat disimpulkan bahwa kualitas merupakan prioritas utama di dalam perusahaan berperan penting dalam pembentukan knowledge management di dalam perusahaan, hal tersebut dapat dilihat dari butir pertanyaan KM15 yaitu: "Perusahaan melakukan review dan evaluasi dari setiap tindakan atau kegiatan yang telah dilakukan" yang memperoleh nilai rata-rata tertinggi yaitu 4.33. Diperoleh juga hasil bahwa knowledge management berpengaruh secara signifikan terhadap sustainability management dan hasil penelitian 
tersebut sejalan dengan penelitian oleh Ahmet Demir, Taylan Budur, Hiwa M. Omer, dan Almas Heshmati pada tahun 2020 dengan judul "Links between knowledge management and organisational sustainability: does the ISO 9001 certification have an effect?". Diperoleh juga hasil bahwa knowledge management berpengaruh secara signifikan terhadap total quality management dan hasil penelitian tersebut sejalan dengan penelitian oleh Amir Honarpour, Ahmad Jusoh, dan Khalil Md Nor pada tahun 2017 dengan judul "Total quality management, knowledge management, and innovation: an empirical study in R\&D units".

\section{- Implikasi Praktis}

Hasil penelitian menunjukan bahwa nilai rata-rata dari variabel sustainability management (Y) menunjukan bahwa perusahaan telah menghargai keberagaman dan menjunjung tinggi Hak Asasi Manusia. Namun, butir pertanyaan dari kuesioner menunjukan bahwa perusahaan masih belum menerapkan desain produk dan layanan yang berorientasi dengan lingkungan. Hal ini tentunya dapat ditingkatkan dengan turut mempertimbangkan desain produk supaya pelaksanaan sustainability management dalam perusahaan dapat berdampak bukan hanya pada aspek ekonomi dan sosial melainkan juga terhadap lingkungan sekitar. Perusahaan juga dapat menoerhatikan pengolahan limbah serta mengurangi penggunaan sumber daya yang membawa dampak buruk bagi lingkungan.

Berdasarkan hasil temuan pada penelitian ini, terdapat 10 butir pertanyaan pada variabel Digital Leadership. Dari 10 butir pertanyaan ini, diketahui bahwa butir pertanyaan kode DL08 memiliki skor rata-rata terendah. Pertanyaan yang dimaksud adalah "Pemimpin merasa nyaman dalam ketidakmenentuan di era digital" dengan nilai rata-rata 3,85. Peranan pemimpin dalam mengadapatasi teknologi digital akan berperan penting terhadap implementasi teknologi di dalam perusahaan. Oleh karena itu ketika seorang pemimpin merasa tidak nyaman pada ketidakmenentuan di era digital maka hal tersebut merupakan hal kurang baik karena perusahaan membutuhkan pemimpin yang fleksibel terhadap perubahan apapun agar perusahaan dapat terus berkembang. Karena pemimpin yang siap dengan ketidakmenentuan di era digital ini akan selalu berusaha mempelajari hal-hal baru, mengikuti perkembangan yang sedang terjadi (up to date) sehingga dapat menjadi contoh bagi para karyawan yang dipimpin dan akan selalu siap dan sigap untuk membantu karyawannya beradaptasi dalam menghadapi perubahan tersebut. hal yang dapat dilakukan oleh seorang pemimpin perusahaan untuk menghadapi ketidakmenentuan di era digital ini adalah dengan selalu mempelajari perkembangan tren yang terjadi serta melakukan kerja sama dengan perusahaan lain yang memiliki spesialisasi pada bidang teknologi digital.

Jika dilihat berdasarkan dimensi Kerjasama Tim memiliki nilai rata-rata terendah karena belum maksimalnya penerapan kerja sama tim di dalam pelaksanaan Total Quality Management. Peranan Total Quality Management tentunya penting agar perusahaan dapat meningkatkan kualitas perusahaan baik secara internal maupun eksternal. Hal yang dapat dilakukan oleh perusahaan untuk meningkatkan dampak dari implementasi Total Quality Management pada perusahaan adalah dengan meningkatkan kerja sama tim dalam perusahaan serta memberikan apresiasi dan memberikan motivasi kepada karyawan atas kinerja baik yang mereka berikan.

Knowledge Management merupakan hal penting yang harus dimiliki oleh perusahaan, melalui Knowledge Management maka Knowledge yang telah dimiliki perusahaan dapat disimpan, disalurkan secara turun menurun kepada para karyawannya dan dapat dikembangkan lebih luas lagi.Hasil temuan dalam penelitian ini menunjukan bahwa Knowledge Storage memiliki nilai rata-rata tertinggi karena data yang telah dikumpulkan perusahaan merupakan sumber pengetahuan utama yang dimiliki oleh perusahaan, dan dari hasil penyimpanan tersebut, data yang telah dikumpulkan dapat digunakan kembali dimasa yang akan datang. Sedangkan Knowledge Creation/Capture memiliki nilai rata-rata terendah karena perusahaan masih belum optimal dalam menghasilkan pengetahuan-pengetahuan baru yang dapat dimanfaatkan untuk kemajuan perusahaan. Cara yang dapat dilakukan oleh perusahaan dalam meningkatkan proses dari knowledge management dalam perusahaan adalah dengan mengembangkan pengetahuan lama yang telah dimiliki serta dengan memberikan reward kepada karyawan yang dapat memberikan ide atau inovasi baru yang dapat digunakan untuk memanjukan perusahaan. 


\section{Kesimpulan dan Saran}

Berdasarkan hasil penelitian yang telah dilakukan oleh peneliti didapatkan beberapa kesimpulan, yaitu Penelitian ini meneliti 389 responden yang sedang bekerja di perusahaan berlokasi di DKI Jakarta. Metode analisis yang digunakan oleh peneliti adalah Uji Validitas, Uji Reliabilitas, Analisis Statistik Deskriptif, Uji Kausal (Kruskal Wallis dan Independent Sample t-Test), Uji Regresi, dan Path Analysis dengan menggunakan variabel independent digital leadership, total quality management, dan knowledge management terhadap variabel dependen sustainability management.

Tingkat sustainability management, digital leadership, total quality management, dan knowledge management pada perusahaan di DKI Jakarta termasuk ke dalam kategori tinggi. Terdapat perbedaan yang signifikan pada Sustatianbility Management, Digital Leadership, dan Total Quality Management jika dibedakan berdasarkan Sumber Data yang didapatkan. Tidak terdapat perbedaan yang signifikan pada Sustatianbility Management, Digital Leadership, dan Total Quality Management jika dibedakan berdasarkan Jenis Kelamin. Terdapat perbedaan yang signifikan pada Sustainability Management, Digital Leadership, dan Knowledge Management jika dibedakan berdasarkan Usia. Sedangkan tidak terdapat perbedaan yang signifikan pada Total Quality Management jika dibedakan berdasarkan Usia. Terdapat perbedaan yang signifikan pada Sustainability Management dan Digital Leadership jika diberdakan berdasarkan Pendidikan Terakhir. Sedangkan tidak terdapat perbedaan yang signifikan pada Total Quality Management dan Knowledge Management jika dibedakan berdasarkan Pendidikan Terakhir. Terdapat perbedaan yang signifikan pada Sustainability Management, Digitasl Leadership, Total Quality Management, dan Knowledge Management jika dibedakan berdasarkan Jenis Perusahaan atau Organisasi Tempat Bekerja. Terdapat perbedaan yang signifikan pada Sustainability Management dan Knowledge Management jika dibedakan berdasarkan Lama Bekerja di Perusahaan. Sedangkan tidak terdapat perbedaan pada Digital Leadership dan Total Quality Management jika dibedakan berdasarkan Lama Bekerja di Perusahaan. Terdapat perbedaan yang signifikan pada Sustainability Management, Digital Leadership, dan Knowledge Management jika dibedakan berdasarkan Posisi atau Jabatan di Perusahaan. Sedangkan tidak terdapat perbedaan yang signifikan pada Total Quality Management jika dibedakan berdasarkan Posisi atau Jabatan di Perusahaan. Terdapat perbedaan yang signifikan pada Sustainability Management, Digital Leadership, dan Knowledge Management jika dibedakan berdasarkan Industri Perusahaan Tempat Bekerja. Sedangkan tidak terdapat perbedaan yang signifikan pada Total Quality Management jika dibedakan berdasarkan Industri Perusahaan Tempat Bekerja. Terdapat pengaruh yang signifikan antara Digital Leadership terhadap Sustainability Management pada perusahaan di DKI Jakarta. Tidak terdapat pengaruh yang signifikan antara Total Quality Management terhadap Sustainability Management pada perusahaan di DKI Jakarta. Terdapat pengaruh yang signifikan antara Knowledge Management terhadap Sustainability Management pada perusahaan di DKI Jakarta. Terdapat pengaruh yang signifikan antara Digital Leadership terhadap Total Quality Management pada perusahaan di DKI Jakarta. Terdapat pengaruh yang signifikan antara Knowledge Management terhadap Total Quality Management pada perusahaan di DKI Jakarta. Terdapat pengaruh yang signifikan antara Digital Leadership terhadap Knowledge Management pada perusahaan di DKI Jakarta. Knowledge Management tidak memainkan peran mediator antara Digital Leadership dan Sustainability Management dengan nilai koefisien jalur sebesar 0,294 yang lebih kecil daripada nilai koefisien jalur Digital Leadership langsung ke Sustainability Management. Knowledge Management memainkan peran mediator dalam hal pengaruh antara Digital Leadership terhadap Total Quality Management dengan nilai koefisien jalur sebesar 0,522 yang lebih besar daripada nilai koefisien jalur Digital Leadership langsung ke Total Quality Management. Sustainability Management dipengaruhi secara langsung oleh Digital Leadership dan Knowledge Management.

Saran peneliti melalui penelitian ini adalah kepada perusahaan harus lebih meningkatkan kepeduliannya mengenai dampak operasional perusahaan terhadap lingkungan, mampu menciptakan desain produk yang berorientasi pada lingkungan, serta juga dapat meningkatkan kepedulian dengan menggunakan fasilitas perusahaan secara efisien. Perusahaan perlu lebih memperhatikan tentang pentingnya peran pemimpin dalam perusahaan dan karyawan. Hasil penelitian dari variabel Total Quality Management adalah tidak signifikan. Hal ini diduga terdapat kesalahan atau kegagalan perusahaan dalam implementasi nilai-nilai dari prinsip Total Quality Management. Dalam penelitian yang dilakukan dimana poin dari pemberian reward atau penghargaan dari perusahaan terhadap karyawan merupakan 
poin dengan rata-rata paling kecil. Penerapan nilai-nilai dari Total Quality Management membutuhkan komitmen dari seluruh entitas dari perusahaan untuk terus mau berkembang memperbaiki diri dan sistem. Untuk itu, perusahaan juga perlu untuk memberikan apresiasi dan juga reward kepada para karyawannya sebagai motivasi yang diberikan perusahaan atas kerja keras dan keterlibatan karyawan yang telah membantu perusahaan untuk berkembang. Hal ini juga didukung dengan pernyataan dari hasil penelitian dimana perusahaan-perusahaan di DKI Jakarta masih kurang dalam memberikan apresiasinya kepada karyawan yang mampu memberikan pengetahuan dan wawasan baru. Untuk itu hal yang dapat dilakukan perusahaan dalam meningkatkan Knowledge Creation antara lain dengan melakukan research and development dan juga memberikan reward sebagai tanda jasa dari perusahaan terhadap karyawan yang mampu untuk menciptakan pengetahuan dan wawasan baru pada perusahaan. Dengan melakukan hal ini diharapkan perusahaan mampu untuk menciptakan pengetahuan dan wawasan baru yang dapat membantu perusahaan terus berinovasi dan juga membantu perusahaan dalam mencegah atau menanggulangi masalah yang terjadi.

\section{Limitasi dan Studi Lanjutan}

Penelitian ini hanya meneliti variabel digital leadership, total quality management, knowledge management, dan sustainability management. Penelitian ini juga terbatas kepada para karyawan yang bekerja dalam perusahaan di DKI Jakarta. Penulis juga mengalami hambatan dimana masih minim nya penelitian yang membahas mengenai variabel-variabel digital leadership dan knowledge management terhadap sustainability management.

\section{Ucapan Terima Kasih}

Penulis mengucapkan terima kasih yang sebesar-besarnya kepada Tuhan Yang Maha Esa, orang tua penulis, dosen pembimbing, seluruh teman penulis, dan Universitas Bina Nusantara yang telah memberikan banyak dukungan dan bantuan kepada penulis baik secara langsung maupun tidak langsung sehingga mampu membuat penulis menyelesaikan penelitian ini dari awal hingga selesai.

\section{Referensi}

Al-Khouri, A. M. (2013). Environment Sustainability in the Age of Digital Revolution: A Review of the Field. American Journal of Humanities and Social Sciences. https://doi.org/10.11634/232907811301391

Aziz, M. S. (2020). Tinjauan Literature tentang Knowledge Management: Definisi Konseptual, Dasar Teoritik dan Praktik Knowledge Management, serta Perkembangan Penelitiannya dalam Bidang Ilmu Manajemen dan Pendidikan. Intizam, Jurnal Manajemen Pendidikan Islam, Vol 3(2), 1-34.

Baumgartner, R. J., \& Rauter, R. (2017). Strategic perspectives of corporate sustainability management to develop a sustainable organization. Journal of Cleaner Production. https://doi.org/10.1016/j.jclepro.2016.04.146

Charantimath, P. M. (2017). Total Quality Management (3rd ed.). Pearson Education.

Choudhury, D. D. P. (2019). Sustainability Management. Zorba Books.

Crosby, P. B., Deming, W. E., Juran, J. M., \& Suarez, J. G. (1992). Three Experts on Quality Management : by. 92.

Daqar, M. A., \& Constantinovits, M. (2020). The role of total quality management in enhancing the quality of private healthcare services. Problems and Perspectives in Management, 18(2), 64-78. https://doi.org/10.21511/ppm.18(2).2020.07

Deming, W. E. (2000). The New Economics For Industry, Government, Education (Second Edi). MIT Press.

Demir, A., Budur, T., Omer, H. M., \& Heshmati, A. (2021). Links between knowledge management and organisational sustainability: does the ISO 9001 certification have an effect? Knowledge Management Research and Practice, 00(00), 1-14. https://doi.org/10.1080/14778238.2020.1860663

Fatimah Mardani, R. M., \& Wahono, B. (2017). e-jurnal Riset Manajemen PRODI MANAJEMEN Fakultas Ekonomi Unisma Website : 51-69.

Fernández, M. G.-. (2015). How to measure knowledge management: dimensions and model. VINE Journal of Information and Knowledge Management Systems, 45(1pp). https://doi.org/http://dx.doi.org/10.1108/VINE-10-2013-0063

Hota, P., Nayak, B., \& Sarangi, P. (2021). Materials Today: Proceedings Integration of total quality 
management principles to enhance quality education in management institutions of odisha. Materials Today: Proceedings, xxxx. https://doi.org/10.1016/j.matpr.2020.10.129

Ichijo, K., Nonaka, I., \& Editors. (2007). Knowledge Creation and Management: New Challenges for Managers. Oxford University Press, Inc. 198 Madison Avenue, New York, New York 10016.

Iqbal, A., Latif, F., Marimon, F., Sahibzada, U. F., \& Hussain, S. (2019). From knowledge management to organizational performance. Journal of Enterprise Information Management.

Kianto, A., Vanhala, M., \& Heilmann, P. (2016). The impact of knowledge management on job satisfaction. Journal of Knowledge Management, 20(4), 621-636. https://doi.org/10.1108/JKM10-2015-0398

Kiesnere, A. L., \& Baumgartner, R. J. (2019). Sustainability management in practice: Organizational change for sustainability in smaller large-sized companies in Austria. Sustainability (Switzerland). https://doi.org/10.3390/su11030572

Kim, J., \& Kim, J. (2018). Corporate sustainability management and its market benefits. Sustainability, $10(5), 1455$.

Knapp, T. R., \& Brown, J. K. (1995). Ten measurement commandments that often should be broken. Research in Nursing \& Health, 18(5), 465-469. https://doi.org/10.1002/nur.4770180511

Kumar, R. (2019). Research Methodology: A Step-by-Step Guide for Beginners. In SAGE.

Le, P. B., \& Lei, H. (2017). How transformational leadership supports knowledge sharing: Evidence from Chinese manufacturing and service firms. Chinese Management Studies, 11(3), 479-497. https://doi.org/10.1108/CMS-02-2017-0039

Lind, D. A., Marchal, W. G., \& Wathen, S. A. (2017). Statistical Techniques in Business \& Economics. In Economics.

Mihardjo, L. W. W., Sasmoko, S., Alamsjah, F., \& Elidjen, E. (2019). Digital leadership role in developing business model innovation and customer experience orientation in industry 4.0. Management Science Letters. https://doi.org/10.5267/j.msl.2019.6.015

Mohapatra, S., Agrawal, A., \& A., S. (2016). Designing Knowledge Management-Enabled Business Strategies: A Top-Down Approach. In Springer Verlag Books.

Muruganantham, G., Vinodh, S., Arun, C. S., \& Ramesh, K. (2016). Total Quality Management \& Business Excellence Application of interpretive structural modelling for analysing barriers to total quality management practices implementation in the automotive sector. 3363(August). https://doi.org/10.1080/14783363.2016.1213627

Nayebi, H. (2020). Advanced Statistics for Testing Assumed Casual Relationships. Springer.

Obeidat, B., Hashem, L., \& Masa'deh, R. (2018). The Influence of Knowledge Management Uses on Total Quality Management Practices in Commercial Banks of Jordan. Modern Applied Science, 12(11), 1. https://doi.org/10.5539/mas.v12n11p1

Oberer, B., \& Erkollar, A. (2018). Leadership 4.0: Digital Leaders in the Age of Industry 4.0. International Journal of Organizational Leadership. https://doi.org/10.33844/ijol.2018.60332

Pantouvakis, A., \& Vlachos, I. (2020). Talent and leadership effects on sustainable performance in the maritime industry. Transportation Research Part D: Transport and Environment, 86, 10244. https://doi.org/10.1016/j.trd.2020.102440

Putra, I. I. (2020). Statistik Ketenagakerjaan DKI Jakarta 2019. https://statistik.jakarta.go.id/statistikketenagakerjaan-dki-jakarta-2019/

Razmerita, L., Phillips-Wren, G., \& Jain, L. C. (2016). Advances in knowledge management: An overview. Intelligent Systems Reference Library, 95, 3-18. https://doi.org/10.1007/97-3-66247827-1_1

Rudito, P., \& Sinaga, M. F. N. (2017). Digital Mastery, Membangun Kepemimpinan Digital untuk Memenangkan Era Disrupsi. Gramedia Pustaka Utama.

Saputra, N., \& Saputra, A. M. (2020). Transforming into Digital Organization by Orchestrating Culture, Leadership, and Competence in Digital Context. GATR Global Journal of Business Social Sciences Review. https://doi.org/10.35609/gjbssr.2020.8.4(2)

Sekaran, U., \& Bougie, R. (2016). Research Method for Business Textbook: A Skill Building Approach. John Wiley \& Sons Ltd.

Setiawan, W. (2017). Era Digital dan Tantangannya. Seminar Nasional Pendidikan, 1-9.

Shahzad, M., Qu, Y., Ur Rehman, S., Zafar, A. U., Ding, X., \& Abbas, J. (2020). Impact of knowledge absorptive capacity on corporate sustainability with mediating role of CSR: analysis from the 
Asian context. Journal of Environmental Planning and Management, 63(2), 148-174. https://doi.org/10.1080/09640568.2019.1575799

Soltani, Z., \& Navimipour, N. J. (2016). Customer relationship management mechanisms: A systematic review of the state of the art literature and recommendations for future research. Computers in Human Behavior, 61, 667-688. https://doi.org/10.1016/j.chb.2016.03.008

Stage, F. K., Carter, H. C., \& Nora, A. (2004). Path Analysis: An Introduction and Analysis of a Decade of Research. Journal of Educational Research, 98(1), 5-13. https://doi.org/10.3200/JOER.98.1.513

Tasleem, M., Khan, N., \& Nisar, A. (2019). Impact of technology management on corporate sustainability performance: The mediating role of TQM. International Journal of Quality and Reliability Management. https://doi.org/10.1108/IJQRM-01-2018-0017

Vial, G. (2019). Understanding digital transformation: A review and a research agenda. In Journal of Strategic Information Systems. https://doi.org/10.1016/j.jsis.2019.01.003

Wagimin, Kusrini, E., Ali, J., \& Helia, V. N. (2019). The effect of leadership on employee performance with Total Quality Management (TQM) as a mediating variable in Indonesian petroleum companies: A case study. International Journal of Integrated Engineering, 11(5), 180-188. https://doi.org/10.30880/ijie.2019.11.05.023

Wilkesmann, M., \& Wilkesmann, U. (2018). Industry 4.0 - organizing routines or innovations? VINE Journal of Information and Knowledge Management Systems. https://doi.org/10.1108/VJIKMS04-2017-0019

Wrede, M., Velamuri, V. K., \& Dauth, T. (2020). Top managers in the digital age: Exploring the role and practices of top managers in firms' digital transformation. Managerial and Decision Economics, 4l(8), 1549-1567. https://doi.org/10.1002/mde.3202

Yusr, M. M., Mokhtar, S. S. M., Othman, A. R., \& Sulaiman, Y. (2017). Does Interaction between TQM Practices and Knowledge Management. International Journal of Quality \& Reliability Management, Https://Doi.Org/10.1108/IJQRM-09-2014-0138. 